\title{
예비유아교사를 위한 내러티브 스토리텔링 수업설계 구안*
}

강문숙(姜文淑 $)^{* *}$

\section{논문 요약}

본 연구는 예비유아교사를 위한 내러티브 스토리텔링 수업설계안을 개발하고자 하였다. 이를 위한 연구방법 으로 개발연구(Rechey \& Nelson, 1996)를 사용하였으며, 개발연구의 연구방법과 절차는 문헌분석, 사례분석을 통해 핵심가치, 설계전략, 지원요소, 프로세스를 도출하여 수업설계 초안을 구안하고, 전문가 형성평가와 예비유 아교사를 대상으로 수업 적용하였으며, 개선점을 중심으로 수정 - 보완하여 최종의 절차적 청사진을 구안하였다. 연구결과, 내러티브 스토리텔링 수업설계안이 도출되었고, 구체적인 내용은 다음과 같다. 첫째, 내러티브 스토 리텔링의 특성을 반영한 수업설계안은 Egan(1986)의 스토리형식 모형(Story Form Model)과 비교 · 보완하는 과정을 거쳐, 체제적 수업설계안을 제공할 수 있다. 둘째, 내러티브 스토리텔링 수업은 재생가능한 매체제작과 감각적인 성찰을 통해 상호 간 피드백과 피드포워드 될 수 있는 순환적인 사고와 과제해결의 기회를 제공할 수 있다. 셋째, 내러티브 스토리텔링 수업은 다양한 영역에서 교수자와 학습자의 경험과 삶을 이야기 하고, 이야기 구성을 통해 의미를 생성하고 유기적인 관계를 형성할 수 있다. 즉, 아이스브레이킹과 브레인스토밍 기법을 활용 하여 다양한 아이디어와 관계지향적 의사소통 전달체의 역할이 가능할 수 있다. 특히, 본 수업설계안은 성찰활동 을 통해 활동을 점검하고, 각 단계의 결과물은 다음 단계의 입력 자료가 될 수 있는 각 단계별 수업이 서로 연결 되고 이어지는 연동성이 존재한다.

주요어 : 예비유아교사, 내러티브 스토리텔링, 수업설계

* 이 논문은 2013년 대한사고개발학회 학술대회에서 발표한 것을 일부 수정·보완한 것임.

** 한국국제대학교 유아교육과 조교수 


\section{I. 서론}

내러티브는 인간이 가지고 있는 가장 기본적이고 간편한 행동 양식이며(Polkinghorne, 1988), 교사와 학습자의 경험과 삶을 구성하고 이해하는 중요한 수단으로, 최근 교육학 분야에서 이야 기를 적극 활용하여 교수자와 학습자의 상호작용, 교과교육의 방향, 교수자의 역할에 대한 관점 에서 논의하며 교과교육과 교사양성의 적용 가능성, 교육과정 분야의 질적 연구방법 등에서 다 양하게 진행되고 있다(강현석, 2005). 특히, 교사의 수업활동을 이해하고 보다 타당한 교사양성 교육과정과 수업의 구성에서 내러티브의 중요성이 인식되고 있다(Egan, 1986).

이러한 인식에서 내러티브는 지식과 정서를 다루기 위해 인간이 가지는 인지 도구이며, 학습 자가 정서적으로 더욱 몰입하게 하는 것도 '이야기'이다(Egan, 1992). 내러티브는 학습자를 몰입 과 흥미로 안내하는 주된 매개체가 될 수 있으며, 맥락적 내러티브는 지식의 내면화와 학습의 순환성을 도와주는 역할을 한다. 그러므로 교육은 교사와 학습자가 자신의 이야기를 하고 상대 방의 이야기를 들어주는 행위로(Clandinin \& Connelly, 2000), 자연스러운 이야기를 통해서 의 미를 부여받는 스토리 방식(Polkinghorne, 1988)이어야 한다. 즉, 교육은 지식과 교육내용을 바 탕으로 처한 맥락에 조응하고 상황맥락적이고 다양한 경험의 이야기로 새로운 가치를 창출하는 방식(강문숙, 김석우, 2012)의 수업이어야 한다.

내러티브와 관련한 교육학 연구들은 교육학적 측면에서 학교현장의 적용 가능성, 교사교육, 그 외 다양한 학문영역에서 이루어지고 있다(강현석, 2005; Clandinin \& Connelly , 2000). 내러 티브는 교육과정에서 하나의 수단으로서 중요한 의미를 가지며, 동시에 경험을 중심으로 말하는 실천적 지식과 정보의 표현이다. 특히, 수업은 교사와 학생의 대화, 내러티브를 위한 텍스트 교 재, 민감성을 촉진하는 환경인 내러티브로 구성, 진술되어야 한다(강현석, 유동희, 이자현, 이대 일, 2005). 이를 위해 학습자에게 실제적 문제를 제시하고, 보다 미시적 수준에서 스토리를 통한 수업지도안이 요구된다.

내러티브와 유사한 스토리텔링은 일련의 사건들을 스토리 방식으로 연결 짓는 것을 말한다 (Polkinghorne, 1988). 즉, 스토리텔링은 어떤 특정한 기대감을 만드는 사건으로 시작하고, 그 기 대감이 만족감으로 연결되는 결말로 끝나는(ending) 플롯을 가지는데, 이것이 내러티브와 구별 되는 특성이다(Egan, 1986). 스토리텔링은 행동과 사건이 일어나는 순서에 주목하며, 이들을 스 토리 전개와 결말에 미치는 영향에 따라 의미있는 하나의 통일된 자아로 변형시킨다 (Polkinghorne, 1988). 따라서 내러티브는 말 또는 글로 표현된 이야기, 역사, 동화 등의 방식으 로 재현되는 의미생성의 인식과정을 포함한다면, 스토리텔링은 표현양식과 전달방식이라 할 수 있다. 이러한 스토리텔링은 사람의 입으로 전달되기 시작하면서 종이매체, 영상매체, 디지털 매 체 등과 같은 디지털 스토리텔링으로 빠르게 변화하였다. 
그러나 영상매체로 표현된 스토리가 독자나 청중으로 하여금 적극적인 창조를 요구하지는 못 했다. 이와 같이, 컴퓨터와 같은 디지털 매체의 발달은 스토리텔링의 또 다른 전환점을 제공하는 데, 이전의 매체를 통하여서는 실현할 수 없었던 청중과 독자의 능동적인 창조성과 상호작용성 을 부여하면서 디지털 스토리텔링으로 변모하고 있다(Ryan, 2004). 이제 교육 분야에서도 인간 의 삶과 매개하는 스토리텔링의 가치는 여러 가지 매체의 속성과 연결되어 다양한 전달방식으 로 표현된다. 말하자면, 학습자들은 스토리 창작을 위해 워드프로세서를 이용하거나 시공간을 넘어선 스토리 교환, 공유차원의 전자 의사소통 도구를 이용한다(Fusai, Saudelli, Marti, Decortis, \& Rizzo, 2003).

이렇듯 스토리텔링은 단순히 일상적인 의사소통을 넘어 사회적 의미와 교육적 가치 창출로 진화하고 있다. 스토리텔링의 교육적 가치는 이미 존재하는 스토리를 수업내용에 접목하여 들려 주는 수업이(김수향, 2009) 아니라, 다양한 영역에서 이야기하기와 이야기 만들기를 통한 의미 생성의 인식 과정을 포함한다. 교육에서 내러티브 스토리텔링은 창의적인 스토리를 구성하고, 멀티미디어 환경을 통해 구현된다. 학습자들은 이러한 경험을 통해 교육내용과 지식을 기억, 저 장, 전이, 공감함으로써 쉽고 오래 기억할 수 있다(강문숙, 김석우, 2012). 강조하면, 스토리텔링 은 학습내용 및 문제 제시(Jonassen, \& Hernandez-serrano, 2002), 동기유발 차원으로 활용되기 도 하지만, 본 연구에서 내러티브 스토리텔링은 전체적인 학습을 이끄는 교수학습방법 또는 전 략으로서의 활용을 위한 체계적인 수업으로 보는 입장이다.

이러한 의미에서 내러티브 스토리텔링 수업은 첫째, 교육내용을 전달하는 주요수단으로 디지털 기술을 이용하여 캐릭터, 사건, 배경에 관한 복합적인 플롯을 지닌 전달체이다. 즉, 학습자의 경험 을 자연스러운 이야기를 통해서 도입, 전개, 위기, 절정, 결말이라는 행동과 사건의 순서에 따라 변형되고 발전된 스토리 형태와 스토리를 전달할 수 있는 ‘텔링’의 형태를 결합한 것으로 구현된 다. 둘째, 수업에서 교수자와 학습자의 경험과 관점에 따라 해석하는 다양성이 존재한다. 셋째, 개 인이 경험한 실재에 대하여 감성을 자극하여 인지와 감성의 통합적 도구이다(허희옥, 2006). 다시 말해, 내러티브 스토리텔링은 교육과정을 개발하고 시행하는 과정 속에서 지식과 교육내용을 교 수자와 학습자의 경험으로 재구성하고 이해하는 상황맥락적 수업활동이라 할 수 있다.

스토리텔링 연구들은 스토리 창작활동, 학습내용, 문제해결, 교수매체의 교육적 효과와 교과 별 설계, 제작 등(전현정, 강현석, 2009; 허희옥, 2006; Egan, 1986; Fusai, Saudelli, Marti, Decortis, \& Rizzo, 2003; Jonassen, \& Hernandez-serrano, 2002) 다양하게 이루어지고 있다. 하 지만, 수업내용의 맥락성, 수업설계, 수업전략 수립 및 교수매체 제작과 개발 등 구체적인 학습 활동의 과정과 지원이 제시되지 않고 있다. 이를 보완하기 위한 교과수업 중 유아교과교재연구 및 지도법에서 가능할 수 있다. 이 교과는 수업계획, 즉 수업목표의 설정, 활동내용의 선정 및 조직, 활동방법 및 활동유형의 선정, 교수매체 ·교구 선정 및 제작, 평가계획 등 수업활동의 최적 
화를 위한 인쇄매체, 실물, 표본, 영상기기, 교구 등 방법론적인 측면에 초점을 두기 때문에, 본 내러티브 스토리텔링 수업을 충분히 반영할 수 있을 것이다. 하지만, 내러티브와 관련하여 유아 교과교재 연구 및 지도법 교과 연구는 이루어지지 않고 있으며, 소수의 특정 교과목 연구(박향 원, 임부연, 2012; 임수진, 이혜원, 2010) 뿐이다. 또한, 유아교육은 처방적인 수업절차가 적합하 지 못한 것으로 여겨져(Blenkin \& Kelly, 1981), 수업의 질적 차이를 낳고 있다(조희정, 이대균, 2012). 특히, 현장교사들은 내러티브 수업을 가장 어려운 과제로(박향원, 임부연, 2012) 인식하고 있어, 수업의 개선을 위해 그들의 경험적 이야기를 구성한 교과 수업설계가 필요하다.

수업설계는 ARCS 모형, ASSURE 모형, Dick \& Carey 모형, Glaser 모형, Story Form 모형 등이 있다. 이 중 미시적인 측면에서 단위 스토리가 해석적으로 재구성되는 $\operatorname{Egan}(1986)$ 의 스토 리형식 모형(Story Form Model)을 제안한다. Egan(1986)의 스토리형식 모형은 5단계이며, 첫째, 중요성 규명(Identifying importance)단계로, 학습해야 할 주제에 대하여 핵심내용, 왜 학습자에 게 중요한지, 감성적으로 몰입되는 것 등을 고려하여 학습 주제의 중요성을 파악한다. 둘째, 양 분되는 극단을 찾는(Finding binary opposites) 단계로, 학습 주제의 대립 양 극단을 나타낼 수 있는 것이 어떤 내용인지를 찾으며, 이야기를 진행해 나가야 한다. 예를 들어, 큼과 작음, 사랑과 증오, 안전과 공포, 선과 악 등이 있다. 이 때 교수자는 대립하는 양극단을 고려하여, 학습자들이 갈등요소를 만들 수 있도록 풍성한 내러티브 수업으로 이끌어야 한다. 셋째, 스토리 만들기 단계 로, 학습 주제에 근접하고 양극을 가장 극적으로 표현한 내용을 찾는다. 이 단계는 주제를 이야 기 형태로 가장 잘 만들 수 있는 내용을 선택하며, 두 가지 양 극단에 따라 내용을 선정하고 골 라내는 작업이 필요하다. 넷째, 양극에 극적 갈등 해소를 위한 가장 좋은 방법으로 결말 (Conclusion)을 맺는다. 결론 부분에서 이 주제들 간에 존재하는 드라마틱한 갈등을 해결하는 것이 제공되어야 한다. 다섯째, 평가하기 단계로, 학습자들이 주제를 이해했는지, 그 중요성을 파악하고 내용을 어떻게 학습했는지 평가하고 점검한다.

그러나 $\operatorname{Egan}(1986)$ 의 스토리형식 모형은 학습내용 선정방법과 조직에 대해서는 구체적으로 나타내고 있지만, 교수매체 제작과 개발에 구체적인 대안이 제시되지 않고 있다(조희정, 이대균, 2012). 본 연구에서 학습자 개인적 경험 이야기를 스토리로 구성한다는 측면에서 $\mathrm{Egan}(1986)$ 의 스토리형식 모형은 유용하지만, 유아교과교재 연구 및 지도법 교과수업을 구성하거나 매체제작 과 개발에는 보완이 필요하다. 아울러, 유아교육분야에서 수업은 유아교사의 교수기술과 전략을 향상시키는 체계화된 청사진이 없으며(이영석, 2003), 수업은 인간의미와 해석의 주관적인 과정 이 생략된 공학적 합리성(technological rationality)의 이상을 실천하기 위한 단계로 분절된다는 (김영천, 2010) 우려의 인식들도 있다. 이러한 점에서, 내러티브 스토리텔링 수업은 $\operatorname{Egan}(1986)$ 의 스토리형식 모형을 비교·보완하는 과정을 거쳐, 인간의미와 해석이 반영된 실제 교과수업에 적 용한다는 측면에서 기존 유아교과수업과 다른 차별성을 둘 수 있다. 
이에 본 연구는 유아교과교재 연구 및 지도법 교과수업에서 예비유아교사를 위한 내러티브 스토리텔링 수업설계안 청사진을 제공하고자 하며, 이를 위한 연구과제는 다음과 같다. 첫째, 문 헌, 사례분석을 통한 핵심가치, 설계전략, 지원요소, 프로세스를 도출하여 수업설계 초안을 구안 한다. 둘째, 전문가 형성평가와 수업적용 형성평가를 통해 개선사항을 수정·보완한다. 셋째, 내 러티브 스토리텔링 수업설계 절차적 청사진 최종안을 구안한다.

\section{ㅍ. 연구방법}

\section{1. 연구자}

본 연구는 수업체제(Instructional System)가 분절된 수업의 과정과 학습의 복잡성을 단순화하 였을 뿐만 아니라, 수업의 상호작용적 과정을 지나치게 기계화, 탈상황화 되었다는(김영천, 2010) 성찰에서 비롯되었다. 연구자는 교사들이 교육과정을 개발하고 시행하는 과정 속에서 교 수활동을 이해하고 보다 타당한 유아교사양성과정에서 교사와 학습자의 경험과 삶을 이해하는 수단인 내러티브의 중요성을 인식하게 되었다. 특히, 유아교육 교과수업에서 내러티브 스토리텔 링은 미래 교사가 될 예비유아교사들이 갖추어야 할 교수기술과도 직결된다고 생각했다. 이에, 예비유아교사를 위한 내러티브 스토리텔링 수업을 설계한 청사진이 필요하며, 연동성이 존재하 는 수업에 대한 신념을 가지게 되었다.

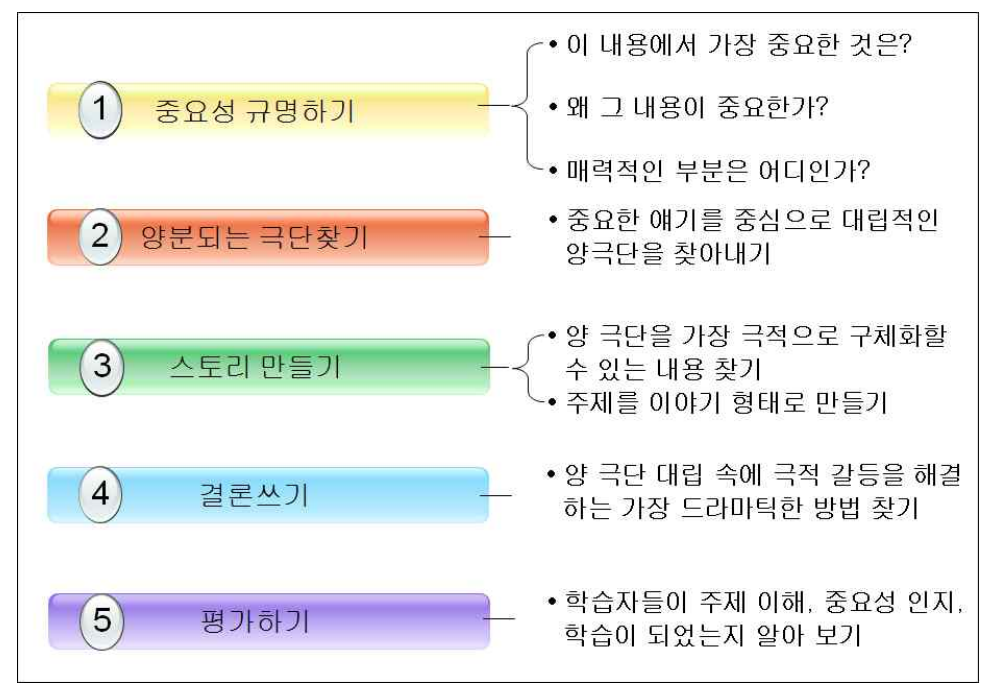

[그림 1] Egan(1986)의 스토리형식 모형(Story Form Model) 


\section{2. 문헌분석}

본 연구는 상황 구체적 산출물을 개발하는 데 Egan(1986)의 스토리형식 모형(Story Form Model)을 비교·보완하여 수업설계안의 정체성을 담보할 수 있도록 하였다. 즉, 구체적 산출물이 나 프로그램의 설계, 개발, 평가 프로젝트를 연구하고, 결론은 상황-구체적, 연구방법은 사례연 구, 평가연구를 하는(Rechey \& Nelson, 1996) 것에 연구의 초점을 두었으며, 수업설계안 산출물 에 대한 타당도 확보와 삼각검증(triangulation)을 하였다. 문헌분석은 내러티브 스토리텔링(강 문숙, 김석우, 2012; 전현정, 강현석, 2009; 허희옥, 2006; Egan, 1986, 1992; Fusai, Saudelli, Marti, Decortis, \& Rizzo, 2003; Jonassen, \& Hernandez-serrano, 2002)과 수업설계 모형(변영계, 이상 수, 2009; Rechey \& Nelson, 1996)의 관련 자료에서 개념과 특성, 핵심가치, 장.단점, 구성요소, 프로세스, 지원요소, 설계전략을 도출하였다.

\section{3. 학습자 분석}

연구 참여자는 2013년 1학기(3월 4일 6월 13일) H대학교 유아교과교재 연구 및 지도법 교과 를 수강하는 유아교육과 3학년 35명(여 34명, 남 1명)을 대상으로 하였다. 학습자는 유아문학교 육, 유아수학교육, 유아과학교육, 유아음악교육 교과에서 교구 및 교재 제작을 통한 모의수업을 경험한 것으로 나타났다. 학습자는 모의수업에서 동기유발을 위한 모의수업의 초반부에서 이미 존재하는 동화나 이야기를 들려주는 경험은 있었으나, 학습자의 삶의 경험적 이야기를 기반으로 창의적 스토리를 구성하고 재창작하여, 전자매체를 활용한 교구제작 수업 경험은 없었다. 또한, 학습자의 컴퓨터 활용 능력은 발표를 위한 PPT 제작 경험 정도였으며, 동영상, 이미지, 음향 등 의 편집 경험은 없었다.

\section{4. 형성평가 I (Focus Group Interview)}

본 연구는 초점집단 면담법(Focus Group Interview : 이하 FGI)으로, 유아교육, 내러티브 스토 리텔링, 수업설계 전문가 총 6명을 대상으로 전문가 형성평가를 실시하였다. FGI 방법은 전자메 일, 전화, 인터뷰를 하였으며, 평가항목 및 질문문항은 수업설계안 개발의 목적에 부합하고, 평 가 요소가 포함된 항목을 작성하여 교육평가 전문가 2 인의 검증을 거친 후, 인터뷰 대상자들에 게 전자메일로 전송하여 평가 내용을 충분히 검토 받았다. 평가 항목 및 질문내용은 수업설계안 의 목적 및 필요성, 이론적 배경, 내러티브 스토리텔링의 핵심가치, 학습활동 프로세스, 프로세 스별 지원요소, 각종 지원도구, 학습 환경, 설계안의 청사진, 수업 적용성 등 평가 항목별 정성적 
평가내용을 자유응답으로 기록하여 FGI에 이용하였다. 인터뷰 내용은 인터뷰 대상자의 동의를 얻어 녹취 후 전사하였으며, 설계안의 주요 항목별 특징과 보완할 내용을 중심으로 분류한 후, 개선 자료로 활용하였다.

전문가 형성평가는 문헌분석을 바탕으로 유아교육 교수전문가 $(\mathrm{K}, \mathrm{J})$, 내러티브 스토리텔링 내 용 전문가 $(\mathrm{K}, \mathrm{H})$, 수업설계 전문가 $(\mathrm{P}, \mathrm{M})$ 총 6명을 대상으로 인터뷰하였으며, 다양한 출처로부터 필요한 정보를 얻는 것을 목적으로 하였다. 전문가 대상자 $\mathrm{K}$ 와 $\mathrm{J}$ 는 유아교과교재 연구 및 지도 법 교재를 발간하고, 강의 경력 10 년 이상인 대학교수이며, 전문가 $\mathrm{K}$ 는 5년 이상 된 내러티브 연구자이며, 전문가 J는 10 년 이상 스토리텔링 강의경력이 있는 시간강사이며 컨텐츠 개발 경력 이 있다. 전문가 $\mathrm{P}$ 와 $\mathrm{M}$ 은 교육공학전공 박사로서 10 년 이상 수업설계와 프로그램 개발 경험이 있는 수업설계자들이다. 인터뷰 문항은 개방형으로 미리 작성하여 교육평가 전문가로부터 검토 를 받아 수정·보완하였으며, 일대일 심층면접법을 원칙으로 하고, 여의치 않은 경우에는 전화 혹은 전자메일을 이용하였다.

<표 1> 전문가 형성평가를 위한 질문내용

질문영역

핵심 가치

수업설계 전략

학습자와 교수자 활동, 교수자의 지식, 기능, 태도, 학습자
사항, 개선할 활동, 학습자 수행 효과와 효율을 위한 지원

내러티브 스토리텔링 특성을 반영한 교과 관련 단계, 교수자와 학습자활동, 구성요

수업설계

프로세스

유아교과교재 연구 및 지도법의 개넘과 특성, 교과의 장단점, 내러티브 스토리텔링 의 개념 및 특성, 내러티브 스토리텔링 장단점

소별 배치, 흐름, 학습자 모니터링, 정보수집, 학습과정과 결과 공유, 의사소통, 팀

원들 간의 상호작용, 필요한 전략

지원요소

학습자 지원요소, 과제 달성을 위한 설계와 결과물 제작 지원요소

인터뷰는 사전에 목적을 간략히 설명하고, 실제 인터뷰 진행 전에 질문지를 전자메일로 발송 하여 생각할 수 있는 시간을 주어 심도 있는 답변을 유도했다. 본 연구에 더 필요하다고 생각한 추가적인 질문은 전자메일을 이용하여 보충하였다. 인터뷰 결과 분석은 핵심가치, 설계전략, 프 로세스 및 지원요소, 학습 환경 지원 항목을 구성요소들에 근거하여 분류하였으며, 현존자료 접 근이 가능하도록 계획서를 작성하여 구체화하였다.

\section{5. 형성평가 II (수업적용)}

현장적용 형성평가는 본 교과수업에서 내러티브 스토리텔링을 이해하고 팀 구성 후, 학습목 
표와 주제선정, 스토리를 구성하고 재창작하였다. 전개단계에서 '스토리텔링 수업기획안'을 작 성하여 멀티미디어 교수매체로 제작·발표하고, 평가와 성찰활동을 하였다. 이 과정에서 아이스 브레이킹과 브레인스토밍 기법으로 창의적인 아이디어를 생성·수렴하는 의사결정이 이루어졌 다. 자료수집방법은 심층면담자료, 성찰일지, 연구자 저널을 중심으로 분석하였다. 성찰일지는 과제해결 과정을 단계마다 자유롭게 기술토록 하고, 심층면담은 본 수업에 관심과 인터뷰 희망 자를 대상으로 3회, 총 6시간 소요되었다. 연구자 저널은 각 단계마다 작성하고, 연구결과에 사 용하였다. 수업적용 기간은 10 주에 걸쳐 진행되었으며, 1 주부터 5 주까지는 유아교과교재 연구 및 지도법 교과 이론수업(강의식), 6주부터 15주까지는 본 수업설계안을 적용하였다. 즉, 6 주와 7주는 유아교과교재 연구 및 지도법 교과에서 수업기획안, 내러티브 스토리텔링관련 이론, 수업 운영 방법, 팀 구성, 역할분담, 결과물 워크시트에서 제시한 과제 중심 전체적인 과정을 안내하 고, 스토리 주제설정을 위해 자신의 경험을 이야기하는 시간을 통해 서로 이해하는 만남을 가졌 다. 8 주는 중간고사, 9 주부터 13 주까지는 스토리 개발에서 최종 결과물 산출, 14 주와 15 주는 평 가하기와 성찰하기로 종료하였다. 수집된 자료는 의미 있는 단어를 추출하여 자료를 범주화하고 반복적 주제들을 발견하게 되는 과정을 거쳐(김영천, 2006), 수업설계안의 강점과 개선점으로 분 류하고, 연구자의 저널은 분석 및 해석의 과정에 사용되었다.

\section{6. 신뢰도와 타당도}

본 연구는 복합적인 서로 다른 유형들(Lincoln \& Guba, 1985)을 사용하여 첫째, 현장 사례를 중심으로 한 문서 자료, 인터뷰, 인터넷 자료 등 서로 다른 복합적인 출처를, 둘째, 문헌분석, 인 터뷰, 사례분석 등 서로 다른 복합적인 연구방법을, 셋째, 유아교육, 내러티브 스토리텔링, 수업 설계 전문가 등 서로 다른 관점에서 조언해 줄 수 있는 복합적인 연구자를 참여시키고, 넷째, 내러티브 스토리텔링, 유아교과교재 연구 및 지도법 교과, 수업설계, 학습지원 등의 서로 다른 이론들을 기반으로 하였다. 또한, 인터뷰 참가자에게 결과분석 자료를 제공하고, 구성원 검토를 통해 오류와 의견을 반영하였다. 


\section{III. 연구결과}

\section{1. 문헌분석}

1) 수업설계안의 핵심가치

유아교과교재 연구 및 지도법 교과수업에서 내러티브 스토리텔링의 핵심가치는 첫째, 이야기 행위이다. 교육은 이야기를 통해서 의미를 부여받는 스토리 방식이다(Clandinin \& Connelly, 2000; Polkinghorne, 1988). 즉, 스토리는 교육내용인 '무엇'이고, 스토리텔링은 내러티브 전달 방 법인 '어떻게'에 해당된다. 둘째, 스토리 창작활동은 이야기를 만들고 전달하는 가운데 의사소통 능력, 상상력, 창조력, 역동적인 상호작용을 할 수 있는 창조적 활동이다(허희옥, 2006). 셋째, 내 러티브 스토리텔링은 인간적 정서를 형성해가는 도구이다(Egan, 1992). 사람과 사물의 본질을 전달하는 과정에서 스토리가 개입되며, 스토리를 매체의 특성에 맞게 표현, 전달하는 긍정적인 매개체 구실을 한다. 넷째, 수업내용과 수업소재의 전달도구로, 신화, 전설, 애니메이션, 음악, 텍 스트 등 다양한 매체를 통해 전달한다. 따라서 예비유아교사는 유아를 위해 수업계획을 수립하 고 전개하는 적극적인 역할과 스토리 속의 다양한 삶을 이해하는 안내자의 역할을 해야 한다.

\section{2) 수업설계 전략}

본 연구는 유아교과교재 연구 및 지도법 교과수업에서 수업설계안의 문제점, 핵심 가치와 비 교하여 둘 사이의 차이(gap)를 중심으로 설계전략을 도출하였다. 첫째, 유아교과교재 연구 및 지도법 교과수업에서 내러티브 스토리텔링의 목표와 내용을 강조하여 스토리텔링 수업설계 과 정의 원리를 따르고 있다. 둘째, 창의적 사고, 역동적인 상호작용성 등 복합적으로 발달하는 개 념이다. 셋째, 이야기를 만드는 과정(내러티브)과 이야기를 전달하는 과정(스토리텔링)을 포함한 다. 넷째, 단순한 스토리 창작을 넘어 수업설계 모형, 지원도구 등 역동적인 활동이 전개되어 복 합적으로 융합되어야 한다. 유아교과교재 연구 및 지도법 교과수업에서 내러티브와 스토리텔링 의 공통적 요소는 첫째, 내러티브 이해라는 초기상태에서 스토리텔링 이해, 스토리 창작활동을 통해 교수매체 제작·개발, 팀 발표를 통해 성찰과 평가라는 최종상태에 도달하는 것이다. 둘째, 순환적 사고는 예비유아교사들이 갖추어야 할 자질이다. 이는 재생가능한 매체제작과 성찰을 통 해 상호 간 피드백과 피드포워드 될 수 있다. 셋째, 교수매체는 ‘리텔링’을 위한 교수자료이다. 
<표 2> 내러티브 스토리텔링 수업설계 전략

\begin{tabular}{|c|c|}
\hline 내러티브의 문제점 & 스토리텔링 수업설계 전략 \\
\hline $\begin{array}{l}\text { 내러티브 스토리텔링에 } \\
\text { 관한 개념 정의 부족 }\end{array}$ & $\begin{array}{l}\text {-수업설계의 핵심가치와 선행 연구결과물 사이의 차이 발견 } \\
\text {-해당 차이를 이야기형식 모형 이론으로 극복할 수 있는지 확인 }\end{array}$ \\
\hline $\begin{array}{l}\text { 내러티브에 관한 구체적인 } \\
\text { 프로세스가 존재하지 않음 }\end{array}$ & $\begin{array}{l}\text {-프로세스에서 이야기형식 모형을 제시하고, 유아교과교재 연구 및 지 } \\
\text { 도법 교과와 관련하여 내러티브 스토리텔링의 핵심가치를 구현할 수 } \\
\text { 있도록 프로세스화 }\end{array}$ \\
\hline 프로세스별 지원요소 부재 & -수업설계의 지원요소를 교과교재 수업에 맞추어 변형하여 사용 가능 \\
\hline $\begin{array}{c}\text { 프로세스별 학습 결과물에 } \\
\text { 대한 안내 부족 }\end{array}$ & $\begin{array}{l}\text {-프로세스별 결과물을 바탕으로 내러티브 스토리텔링 수업설계 진행 } \\
\text { 단계에 따른 학습 결과물 도출 }\end{array}$ \\
\hline
\end{tabular}

\section{3) 수업설계의 단계별 지원요소}

문헌분석(변영계, 이상수, 2009; Rechey \& Nelson, 1996; Egan, 1986)을 통한 내러티브 스토리 텔링 수업설계의 단계별 지원요소는 <표 3>과 같다.

\section{<표 3> 내러티브 스토리텔링 수업설계의 단계별 지원요소}

\begin{tabular}{|c|c|c|c|}
\hline \multirow{2}{*}{ 프로세스 } & \multicolumn{3}{|c|}{ 내러티브 스토리텔링 단계별 지원요소 } \\
\hline & 교수자원(Instruction) & 안내지침(Infobase) & 도구(Tools) \\
\hline $\begin{array}{l}\text { 내러티브 } \\
\text { 스토리 } \\
\text { 텔링 } \\
\text { 이해하기 }\end{array}$ & $\begin{array}{l}\text { 유아교과교재 연구 및 지도법 관련 내러 } \\
\text { 티브 스토리텔링 개넘 이해하기 } \\
\text { 프로세스 Resource } \\
\text { 학습결과물 사례제시(스토리텔링 온라인 } \\
\text { 자료, 프리젠테이션 자료, 학습결과물) }\end{array}$ & $\begin{array}{l}\text { 유아교과교재 연구 및 지도 } \\
\text { 법 교과수업 안내 자료 } \\
\text { 수업 방법 안내 } \\
\text { 평가 계획 수립 지침 } \\
\text { 다양한 학습결과물 형태지침 }\end{array}$ & $\begin{array}{l}\text { 유아교과교재 관련 교재 } \\
\text { 수업 온라인 양식 } \\
\text { 학습결과물 양식 } \\
\text { 팀활동 보고서/기록지 } \\
\text { 성찰일지 }\end{array}$ \\
\hline $\begin{array}{l}\text { 내러티브 } \\
\text { 스토리텔 } \\
\text { 링목표설 } \\
\text { 정하기 }\end{array}$ & $\begin{array}{l}\text { 목표 설정 관련 정보 제시 및 사례 제시 } \\
\text { 중요한 이유, 개인 경험적인 자료 } \\
\text { 학습내용 중요도/ 내용간 연관성자료제시 }\end{array}$ & $\begin{array}{l}\text { 목표 설정 관련 지침 } \\
\text { 목표설정을 위한 지침 } \\
\text { 목표 설정 관련 사례 지침 }\end{array}$ & $\begin{array}{l}\text { 목표설정계획서/보고서 } \\
\text { 학습 내용의 중요도와 내 } \\
\text { 용간의 연관성 자료 }\end{array}$ \\
\hline $\begin{array}{l}\text { 팀구성 및 } \\
\text { 역할분담 } \\
\text { 하기 }\end{array}$ & $\begin{array}{l}\text { 팀 구성 샘플 자료 } \\
\text { 역할분담 방법 안내 } \\
\text { 아이스 브레이킹 자료 }\end{array}$ & $\begin{array}{l}\text { 팀 구성 지침 } \\
\text { 역할분담 방식 지침 }\end{array}$ & $\begin{array}{l}\text { 팀 활동 계획서 } \\
\text { 역할분담관련 양식 }\end{array}$ \\
\hline $\begin{array}{l}\text { 내러티브 } \\
\text { 스토리 } \\
\text { 주제 } \\
\text { 설정하기 }\end{array}$ & $\begin{array}{l}\text { 다양한 경험 스토리 주제 설정 방법 예 } \\
\text { 시자료(동영상,스토리텔링자료 등) } \\
\text { 아이디어 생성도구 방법 자료 } \\
\text { - Story Form 모델(1단계)-중요성 규명 } \\
\text { 하기 방법 안내 자료 }\end{array}$ & $\begin{array}{l}\text { 내러티브 스토리주제설정 방 } \\
\text { 법지침(브레인스토밍기법) } \\
\text { 아이디어 도구 사용 안내서 } \\
\text { - Story Form 모델(1단계) } \\
\quad \text { 방법 지침 }\end{array}$ & $\begin{array}{l}\text { 시청각 매체 } \\
\text { 아이디어 생성도구양식 } \\
\text { - Story Form 모델(1단계) } \\
\quad \text { 양식 제공 }\end{array}$ \\
\hline $\begin{array}{l}\text { 내러티브 } \\
\text { 스토리 } \\
\text { 공유하기 }\end{array}$ & $\begin{array}{l}\text { 내러티브 스토리 공유 방법 자료 } \\
\text { - Story Form 모델(1단계)-중요성 규명 } \\
\text { 하기 안내하기 }\end{array}$ & $\begin{array}{l}\text { 내러티브스토리공유방법지침 } \\
\text { - Story Form 모델(1단계) } \\
\text { 방법 지침 }\end{array}$ & $\begin{array}{l}\text { 내러티브스토리 계획서 } \\
\text { - Story Form 모델(1단계) } \\
\text { 양식 제공 }\end{array}$ \\
\hline
\end{tabular}




\begin{tabular}{|c|c|c|c|}
\hline \multirow{2}{*}{ 프로세스 } & \multicolumn{3}{|c|}{ 내러티브 스토리텔링 단계별 지원요소 } \\
\hline & 교수자원(Instruction) & 안내지침(Infobase) & 도구(Tools) \\
\hline $\begin{array}{l}\text { 컨셉 } \\
\text { 초안잡기 }\end{array}$ & $\begin{array}{l}\text { 아이디어 생성도구 사용 방법 } \\
\text { 컨셉 초안(발단, 전개, 위기, 절정, 결말 } \\
\text { 5단계) 방법 자료 } \\
\text { - Story Form 모델(2단계)-양분되는 양 } \\
\quad \text { 극단 찾기 방법 안내 자료 }\end{array}$ & $\begin{array}{l}\text { 아이디어 도구 사용 안내서 } \\
\text { 컨셉 초안(발단, 전개, 위기, } \\
\text { 절정, 결말 } 5 \text { 단계)방법 지침 } \\
\text { - Story Form 모델(2단계) } \\
\quad \text { 방법 지침 }\end{array}$ & $\begin{array}{l}\text { 아이디어 생성도구 } \\
\text { 컨셉 초안 } 5 \text { 단계 양식지 } \\
\text { - Story Form 모델(2단계) } \\
\text { 양식 제공 }\end{array}$ \\
\hline $\begin{array}{c}\text { 컨셉 } \\
\text { 개요잡기 }\end{array}$ & $\begin{array}{l}\text { 주제, 기획의도, 등장인물, 줄거리 등 간 } \\
\text { 단한 개요 방법 자료 } \\
\text { - Story Form 모델(3단계)-스토리 만들 } \\
\quad \text { 기 방법 안내 자료 }\end{array}$ & $\begin{array}{l}\text { 주제, 등장인물, 줄거리 등 } \\
\text { 개요방법 자료방법 지침 } \\
\text { - Story Form 모델(3단계) } \\
\quad \text { 방법 지침 }\end{array}$ & $\begin{array}{l}\text { 주제, 등장인물, 줄거리 개 } \\
\text { 요방법자료 양식지 } \\
\text { - Story Form 모델(3단계) } \\
\text { 양식 제공 }\end{array}$ \\
\hline $\begin{array}{c}\text { 컨셉 } \\
\text { 구체화하기 }\end{array}$ & $\begin{array}{l}\text { 플롯 구성 방법 안내 자료 } \\
\text { 플롯의 좋은 사례와 좋지 않은 사례자료 } \\
\text { - Story Form 모델(4단계)-결론쓰기 안 } \\
\text { 내 자료 }\end{array}$ & $\begin{array}{l}\text { 플롯 구성 방법 안내서 } \\
\text { 플롯의 좋은 사례 지침 } \\
\text { - Story Form 모델(4단계) } \\
\text { 방법 지침 }\end{array}$ & $\begin{array}{l}\text { 플롯 구성 방법 안내 양식 } \\
\text { 지 } \\
\text { - Story Form 모델(4단계) } \\
\text { 양식 제공 }\end{array}$ \\
\hline $\begin{array}{l}\text { 비주얼 } \\
\text { 시나리오 } \\
\text { 작성하기 }\end{array}$ & $\begin{array}{l}\text { 비주얼시나리오 작성방법 안내 자료 } \\
\text { 비주얼 시나리오 작성 방법 좋은 사례와 } \\
\text { 좋지 않은 사례 자료 }\end{array}$ & $\begin{array}{l}\text { 비주얼 시나리오 작성 지침 } \\
\text { 비주얼 시나리오 작성 } \\
\text { 좋은 사례 지침 }\end{array}$ & $\begin{array}{l}\text { 비주얼 시나리오 구성 양 } \\
\text { 식지 }\end{array}$ \\
\hline $\begin{array}{l}\text { 스토리 } \\
\text { 보드 } \\
\text { 작성하기 }\end{array}$ & $\begin{array}{l}\text { 스토리보드 작성방법 안내자료 } \\
\text { 스토리보드 작성 방법 좋은 사례와 좋지 } \\
\text { 않은 사례 자료 }\end{array}$ & $\begin{array}{l}\text { 스토리보드 사용 지침 } \\
\text { 스토리보드 작성방법 좋은사 } \\
\text { 례와 좋지않은 사례자료 }\end{array}$ & 스토리보드 사용 양식지 \\
\hline $\begin{array}{l}\text { 학습 } \\
\text { 결과물 } \\
\text { 도출하기 }\end{array}$ & $\begin{array}{l}\text { 학습결과물에 대한 피드백 방법 } \\
\text { 학습결과물 우수 사례 }\end{array}$ & $\begin{array}{l}\text { 팀 피드백 촉진 지침 } \\
\text { 학습결과물 작성시 유의지침 }\end{array}$ & $\begin{array}{l}\text { 팀 발표 평가지 } \\
\text { 학습결과물양식 }\end{array}$ \\
\hline $\begin{array}{l}\text { 학습결과 } \\
\text { 물공유/발 } \\
\text { 표하기 }\end{array}$ & $\begin{array}{l}\text { 학습결과물 공유 및 관리 사례 } \\
\text { 학습 결과 발표 방법 }\end{array}$ & $\begin{array}{l}\text { 프리젠테이션 지침 } \\
\text { 학습결과물 공유하기 지침 } \\
\text { (평가결과 추후학습 활용) }\end{array}$ & $\begin{array}{l}\text { 온라인 커뮤니티 } \\
\text { 시청각 매체 } \\
\text { 아이디어 수렴도구 }\end{array}$ \\
\hline $\begin{array}{l}\text { 평가하기 } \\
\quad \text { 및 } \\
\text { 성찰하기 }\end{array}$ & $\begin{array}{l}\text { 웹 학습과정산출물/최종 결과물 평가방법 } \\
\text { 개별, 팀 성찰활동 촉진방법 } \\
\text { 각 프로세스별 성찰활동 } \\
\text { - Story Form 모델(5단계)-평가하기 안 } \\
\text { 내 자료 }\end{array}$ & $\begin{array}{l}\text { 학습과정/산출물 평가지침 } \\
\text { 단계별평가지침(학습자용) } \\
\text { 개별, 팀 성찰활동 촉진지침 } \\
\text { - Story Form 모델(5단계)- } \\
\text { 방법지침 }\end{array}$ & $\begin{array}{l}\text { 평가지 } \\
\text { 개별 /팀활동 성찰일지 } \\
\text { 팀 평가지 } \\
\text { - Story Form 모델(5단계) } \\
\text { 양식 제공 }\end{array}$ \\
\hline
\end{tabular}

\section{2. 내러티브 스토리텔링 수업설계 절차적 청사진 초안}

내러티브 스토리텔링 수업설계 절차적 청사진 초안은 최종안에 함께 제시하였다.

\section{3. 형성평가 I (Focus Group Interview) 결과}

1) 내러티브 스토리텔링 수업설계안의 강점

전문가 형성평가를 바탕으로 수업설계안이 어떻게 표출되었는가를 살펴보았다. 자료의 질적 
분석은 수집된 자료를 중심으로 긍정적 표현 내용을 분석하였다. 첫째, 내러티브 스토리텔링의 가치 실현이 가능하고, 수업설계 모형의 역할이 적절하게 구현되고 있다. 둘째, 핵심가치 구현을 위한 프로세스는 전반적으로 유아교과교재 연구 및 지도법 교과수업에 적합하도록 교과의 보편 성과 수업설계의 특수성, 내러티브 스토리텔링의 핵심문제를 융합하고 있다. 셋째, 본 수업은 브 레인스토밍 기법을 활용하여 다양한 아이디어 생성, 역동적인 상호작용이 가능하다.

\section{2) 스토리텔링의 개선점}

전문가 형성평가를 통해 개선의 내용을 살펴보면 다음과 같다.

첫째, 유아교과교재 교과수업에서 내러티브 스토리텔링의 핵심 가치, 학습목표를 정확하게 설 정하고 난 후, 내러티브를 구성할 필요가 있다.

유아교과교재 연구 교과수업에서 모든 교육내용을 내러티브 스토리텔링에서 포함할 수 있을지가 의문입니다. 어떤 일정한 영역을 정하면 좋겠어요. 학습 대상에 따라 '스토리'의 구성도 달라져야 하 며, 일방적으로 들려주기 식은 학습의 효과가 반감될 수 있어요(2013, 4, 10. 유아교육교수전문가 J, 인터뷰내용).

면담에서, 유아교과교재 교과수업의 모든 학습내용을 스토리로 구성하기에는 학습효과적인 면에서 한계가 있으므로, 이에 알맞게 설계할 수 있는 스토리가 학습 주제를 담아 낼 수 있어야, 핵심내용이 제대로 전달될 수 있음을 알 수 있었다.

둘째, 내러티브 스토리텔링 특성이 잘 드러나도록 $\operatorname{Egan}(1986)$ 의 스토리형식 모형 단계가 프로 세스에 포함되어야 하고, 매체제작 과정에서 구체화하고 정교화가 필요하다.

이건 업무 매뉴얼처럼 자세한 프로세스가 담긴 가이드 정도로 생각됩니다. $\operatorname{Egan}(1986)$ 의 스토리 형식 모형 단계가 프로세스에 녹아 있어야 해요. 이 수업은 학습자들이 개인의 경험을 바탕으로 한 이야기가 기승전결의 복합적인 플롯으로 재창조되어야 내러티브 스토리텔링이라 할 수 있습니다 (2013, 4, 10. 수업설계교수전문가 M, 인터뷰내용).

이와 같이, 내러티브 스토리텔링의 특성이 드러나도록 $\operatorname{Egan(1986)ㅇㅢ~ㅅㅡㅌㅗㄹㅣㅎㅕㅇㅅㅣㄱ~ㅁㅗㅎㅕㅇㅇㅡㄹ~ㅂㅣㄱㅛ~}$ 하고 보완하여야 학습자의 주관적인 이야기를 재창조하여 지식을 내면화할 수 있고, 적용단계를 구체적으로 제시해야 학습의 효과로 연결될 수 있을 것으로 여겨진다. 특히, 스토리의 가상의 상황은 학습자로 하여금 지각적인 경험, 감성, 분위기 등을 언어로 표현하게 하므로, 본 수업은 개인 경험과 상황맥락적인 의미 구성으로 고려되어야한다. 
셋째, 창의적 아이디어를 촉진할 수 있는 아이디어 생성 지원도구가 필요하며, 학습방법, 학습 지원 환경이 수업설계 내에 반영되어야 한다.

스토리가 재미있고, 흥미롭게 진행되려면 아이디어를 모으고, 생성할 수 있는 브레인스토밍 같은 도구가 필요해요. 팀 구성방식에서 학습자 특성, 지원도구가 제시되어야 교육현장에서 제대로 영향 을 줄 수 있습니다(2013, 4, 10. 수업설계교수전문가 P, 인터뷰내용).

일반적인 수업은 구조적이고 개념적인 언어로 이루어지지만, 본 수업은 개인 이야기를 재창 작하고, 감성, 지식의 내면화가 언어로 구성될 수 있다. 이를 위해, 창조적인 의미 구성이 가능하 도록 아이스브레이킹과 브레인스토밍 기법을 활용한 학습 지원도구가 필요하다.

넷째, 내러티브 스토리텔링 수업 특성이 반영되도록 스토리, 시나리오 재창작, 매체 제작 방법 과 스킬을 안내하는 세부적인 내용과 스토리텔러가 되어보는 ‘리텔링' 과정이 필요하다.

자신의 이야기를 만드는 재창조하여 동극이나 신체표현활동 등으로 재활용해야 합니다. 환타지적 인 생각으로 상상을 해보는 거죠. 과거 춘향전이 쾌결춘향전으로 리사이클링되어 스토리가 순환이 되면 더 바람직할 거예요. 스토리를 매체로 옮겨 제작할 경우 저작 도구도 다룰 줄 알아야 합니다 (2013, 4, 10. 스토리텔링내용전문가 K, 인터뷰내용).

자신의 경험적 이야기를 학습내용이 포함된 스토리로 구성하고, 리텔링하는 과정은 순환적인 사고를 할 수 있는 기회를 제공하며, 무엇보다도 매체 제작과 개발에 대한 구체적이고 세부적인 안내와 지원이 필요함을 알 수 있다. 일반적인 수업은 ‘리텔링' 과정 없이, 그날의 수업내용을 전달하거나 텍스트나 그림자료 등을 이용하는 것이 대부분이다. 이에 반해, 본 수업은 수업상황, 활동전개 방향 조절, 스토리텔러가 되어보는 ‘리텔링' 이 포함된다.

\section{4. 형성평가 II(수업적용) 결과}

\section{1) 수업설계안의 강점}

수업적용에서 강점은 팀워크 형성, 창의적 결과물 도출, 순환적 사고, 유기적인 관계형성이 이루어진 것으로 나타났다. 첫째, 스토리 구성활동과 스토리 공유과정을 통해 성찰과 팀원의 유 기적인 친밀감이 형성되었다. 둘째, 스토리 주제설정을 통해 목표설정이 명확해지며, 아이디어, 갈등, 스토리 구축을 위한 과제수행 과정뿐만 아니라, 창조적인 학습결과물을 도출하는 과정에 서 순환적 사고와 과제해결의 기회를 제공할 수 있었다. 셋째, 본 수업은 새로운 교수방법으로 
학습자들의 적극적인 참여와 개인의 역량이 향상되었다는 긍정적인 반응이 나타났다. 교사와 학 습자는 수업을 통해서 지식이 내면화되고, 즐거움과 몰입, 진정한 만남을 경험하는 것은 쉽지 않다. 수업은 관계의 장으로, 교수자와 학습자의 맥락뿐 아니라 사회적 모든 맥락이 만나는 장소 이다(Macdonald, 1966). 수업은 고정된 텍스트가 아니라, 끊임없이 변형되는 텍스트이며, 교사 와 학습자는 서로 영향을 주고받는 '관계'가 이루어지는 생생한 만남의 장이다. 이러한 의미에서 내러티브 스토리텔링 수업은 만남을 통한 살아있는 '관계' 수업이 될 수 있다.

\section{2) 수업설계안의 개선점}

수업적용에서 개선점의 내용을 분석한 결과는 다음과 같다.

첫째, 성찰활동에서 합의에 의한 의사결정을 존중하고, 최상의 과제해결에 도달할 수 있는 서 로의 역할을 확인하고 재점검하는 단계가 요구된다.

처음에 정했던 역할이 있었는데, 팀 활동하면서 자신이 맡은 역할이 어렵다고 생각이 들었고, 성 찰시간에 팀원들이 서로 의논하고 역할을 바꿀 수 있는 기회가 필요하다는 의견이 있었어요. 컴퓨 터로 매체제작 할때는 스토리보드로 다시 돌아가거나 스토리를 학습목표에 맞게 되었는지 다시 확 인하고 수정했어요(2013. 5. 2. 예비유아교사 P, 인터뷰내용).

이와 같이, 학습자는 최종결과물을 도출하기 위해 팀원들과 서로 협력하여 의사결정에 이르 는 것을 알 수 있다. 또한 본 수업은 멀티미디어로 재생가능한 매체제작과 성찰활동을 통해 상호 간 피드백과 피드포워드 될 수 있는 순환적인 사고와 과제해결의 기회를 제공할 수 있다.

둘째, 이야기 재창작과정은 어렵고 힘든 작업이었으나, 과학적 개념, 원리, 절차 등과 연계시 켜 학습자의 흥미와 인식 변화, 끊임없이 변형된 최상의 텍스트를 위해 온라인 학습 환경을 적극 활용해야 한다.

수업은 체계적이고 흥미로웠지만, 스토리 재창작할 때, 스토리의 흐름에 맞게 재창작하는 것은 쉽지 않았어요. 경험 이야기를 글이나 말로 표현하는 것이 빨리 나오지 않아 힘들었어요. 우리 팀은 좀 웃기지만, 주제를 넣으면 이야기가 만들어져 나오는 컴퓨터 시스템이 있으면 좋겠다는 애기도 했어요. 하지만 온라인 카페에서 팀원들과 모여 이야기 구성하면서 생각을 나누는 것은 즐겁기도 했어요(2013. 5. 13. 예비유아교사 $\mathrm{M}$, 인터뷰내용).

학습자 면담에서, 본 수업은 재미있고 흥미로웠으나, 학습자들은 이야기 재창작과정에서 다소 어렵고 힘든 여지를 표현하였다. 교수자는 풍성한 내러티브를 위해 주제설정과 컨셉초안잡기에 서 $\operatorname{Egan}(1986)$ 의 중요성 규명과 양분되는 극단의 내용을 찾을 수 있는 구체적인 안내가 필요함 
을 알 수 있다. 그러나 본 수업은 온라인 학습 환경에서 타인의 생각, 공유된 마음을 형성하고, 지식 습득에 효과적인 학습을 이끌 수 있는 긍정적인 반응을 나타내고 있다.

셋째, 결과물 발표, 평가하기에서 피드백과 결과물 수정에 대한 충분한 시간이 필요하다.

마무리단계 발표하기에서 팀 결과물은 나왔지만, 좀 다듬고 각자 발표하는 부분의 역할과 순서, 내용을 짜는데 시간이 많이 부족했고, 너무 바쁘게 시간이 훌쩍 지나갔지만, 한 학기가 꽉찬 느낌은 든다(2013. 4. 27. 예비유아교사 S, 성찰일지).

수업은 그들의 경험을 이야기하고 이해하는 수단이라는 관점에서 행복했지만, 피드백, 평가, 성찰 시간은 추후수업을 위해 충분히 필요하다. 컴퓨터를 활용한 힘든 작업과정에도 불구하고, 서로 과제 를 해결하려는 학습자의 모습에서 제한된 텍스트 수업의 한계를 넘어, 역동적이고 진정한 만남의 '관계' 수업을 경험할 수 있었다(2013. 5. 10. 연구자의 저널).

학습자 면담에서, 수업은 제한된 시간의 한계에서 벗어나 학습자의 개인적 의미와 해석의 주 관성이 포함되어야 함을 알 수 있다. 최종의 수업설계안의 도입단계는 스토리텔링 이해하기, 팀 구성하기 및 역할분담하기, 목표 설정하기, 스토리 주제 설정하기, 스토리 공유하기 과정이다. 전개단계는 역할 재구성하기, 컨셉 초안잡기, 컨셉 개요잡기, 컨셉 구체화하기, 매체제작 방법 이해하기, 비주얼 시나리오 작성하기, 스토리보드 작성하기, 학습결과물 도출하기의 과정이다. 마무리단계는 학습결과물 공유하기 및 발표하기, 리텔링하기, 평가하기 및 성찰하기의 과정이 다. 최종의 수업설계안의 각 단계는 성찰을 통해 활동을 점검하고, 각 단계의 결과물은 다음 단 계의 입력 자료가 될 수 있는 각 단계별 수업이 서로 연결되고 이어지는 연동성이 존재한다. 다 음 <표 4>는 내러티브 스토리텔링 수업설계 절차적 청사진 최종안이며, 초안을 바탕으로 수정. 보완된 부분은 이텔릭체로 표기하였다. 


\section{5. 내러티브 스토리텔링 수업설계 절차적 청사진 최종안}

<표 4> 내러티브 스토리텔링 절차적 수업설계 절차적 청사진 최종안

\begin{tabular}{|c|c|c|c|c|c|c|}
\hline & 학습과정 & \multirow{2}{*}{ 핵심학습활동(교수자/학습자) } & \multicolumn{3}{|c|}{ 핵심활동 지원요소 } & \multirow{2}{*}{ 학습환경 } \\
\hline & 프로세스 & & 안내지침 & 관련 정보 & 도구 & \\
\hline $\begin{array}{l}\text { 내 } \\
\text { 러 } \\
\text { 티 }\end{array}$ & $\begin{array}{c}\text { 내러티브 } \\
\text { 스토리텔링 } \\
\text { 이해하기 }\end{array}$ & $\begin{array}{l}\text { - 유아교과교재 연구 및 지도법 교과 개 } \\
\text { 념, 특성, 장단점, 내러티브 스토리텔 } \\
\text { 링의 개념, 목표, 개념, 방법 도구 사 } \\
\text { 용 안내하기/이해하기 } \\
\text { - 내러티브 스토리텔링 수업 평가 계획 } \\
\text { 안내하기/이해하기 }\end{array}$ & $\begin{array}{l}\text { - 유아교과교재 연구 및 지 } \\
\text { 도법 교과 관련 수업 지 } \\
\text { 침 } \\
\text { - 내러티브 스토리텔링의 } \\
\text { 자료제시하기 } \\
\text { - 평가 계획 수립 지침 }\end{array}$ & $\begin{array}{l}\text { - 교과교재 관련 안내 자 } \\
\text { 료 } \\
\text { - 내러티브관련 안내자료 } \\
\text { - 스토리텔링 관련 자료 } \\
\text { - 프로세스 info } \\
\text { - 온라인과제 탑재안내자료 } \\
\text { - 평가계획 안내 자료 }\end{array}$ & $\begin{array}{l}\text { - 교과교재관련 교재 } \\
\text { - 팀별활동보고서 } \\
\text { - 팀별 회의 기록지 } \\
\text { - 성찰일지 } \\
\text { - 개별학습보고서 }\end{array}$ & $\begin{array}{l}\text { - 내러티브 스토리텔링 평 } \\
\text { 가 계획세우기 자료 제공 } \\
\text { - 평가 도구 제 공 } \\
\text { - 오프라인 환경 }\end{array}$ \\
\hline $\begin{array}{l}\text { 스 } \\
\text { 토 } \\
\text { 리 } \\
\text { 텔 } \\
\text { 링 }\end{array}$ & $\begin{array}{c}\text { 팀 구성하기 } \\
\text { 및 } \\
\text { 역할분담하기 }\end{array}$ & $\begin{array}{l}\text { - 개별 스토리 소개하기를 통한 팀 구성 } \\
\text { 원 이해하기 (학습자 특성 파악하기) } \\
\text { - 학습자특성과 요구에 역할안내하기 } \\
\text { - 팀 구성방식 정하기 (내러티브 스토리 } \\
\text { 텔링 과제 수행 시 인원수, 개인 특기, } \\
\text { 개인과 팀 모임 시간 고려, 불참석에 } \\
\text { 대한 조치 등 규칙 수립 안내) } \\
\text { - 팀 구성하기 } \\
\text { - 팀명, 팀 구호, 팀 규칙 정하기 } \\
\text { - 팀내 리더 퍼실리테이터 정하기 } \\
\text { - 팀원 구성원 역할정하기 (팀내 리더, } \\
\text { 격려자, 기록자, 제작자 등 역할분담 } \\
\text { 하기)/역할 안내하기 } \\
\text { - 내러티브 스토리텔ㄹ링 관련 지식, 자신 } \\
\text { 의 경험이야기, 잘하는 것, 하고 싶고 } \\
\text { 배우고 싶은 역할 안내하기 }\end{array}$ & $\begin{array}{l}\text { - 팀 구성 방식 지침 } \\
\text { - 팀 구성 지침 } \\
\text { - 아이디어 생성도구 안내 } \\
\text { 지침 } \\
\text { - 팀 규칙 정하기 지침 } \\
\text { - 유아문학교육과 관련한 } \\
\text { 지식 안내 지침 } \\
\text { - 과제 해결을 위한 팀원들 } \\
\text { 의 역할 분담 지침 } \\
\text { - 팀 구성원을 이끌어 나가 } \\
\text { 는 팀내 유능한 리더인 } \\
\text { 퍼실리테이터 역할 지침 } \\
\end{array}$ & $\begin{array}{l}\text { - 팀 구성 방식 자료 } \\
\text { - 아이스브레이킹 자료 } \\
\text { - 아이디어 생성을 위한 } \\
\text { 도구 안내 자료 } \\
\text { - 팀 규칙 안내 자료 } \\
\text { - 역할분담 안내 자료 } \\
\text { - 아이디어 생성도구 안내 } \\
\text { 자료 } \\
\text { - 과제 해걸을 위한 팀원 } \\
\text { 들의 역할 분담 안내 자 } \\
\text { 료 } \\
\text { - 팀 구성원을 이끌어 나 } \\
\text { 가는 팀내 유능한 리더 } \\
\text { 인 퍼실리테이터 역할 } \\
\text { 안내 자료 }\end{array}$ & $\begin{array}{l}\text { - 아이디어 생성도구(브레 } \\
\text { 인스토밍, 마인드 맵) } \\
\text { - 역할분담 양식 } \\
\text { - 팀 활동 계획서 } \\
\text { - 팀원들의 역할 분담 안 } \\
\text { 내서 } \\
\text { - 팀리더인 퍼실리테이터 } \\
\text { 역할 안내서 }\end{array}$ & $\begin{array}{l}\text { - 팀빌딩을 위해 필요한 학 } \\
\text { 습자 특성파악 도구 제 공 } \\
\text { - 아이스브레이킹을 위한 } \\
\text { 지침 등 학습지원 요소 } \\
\text { 제공 } \\
\text { - 아이디어 생성도구 자료 } \\
\text { 제공 } \\
\text { - 온/오프라인 학습지원요 } \\
\text { 소 제공 } \\
\text { - 역할분담 양식지 등 제공 } \\
\text { 환경 } \\
\text { - 온라인 커뮤니티 제공 }\end{array}$ \\
\hline
\end{tabular}




\begin{tabular}{|c|c|c|c|c|c|}
\hline 학습과정 & \multirow{2}{*}{ 핵심학습활동(교수자/학습자) } & \multicolumn{3}{|c|}{ 핵심활동 지원요소 } & \multirow{2}{*}{ 학습환경 } \\
\hline 프로세스 & & 안내지침 & 관련 정보 & 도구 & \\
\hline $\begin{array}{l}\text { 내러티브 } \\
\text { 스토리텔링 } \\
\text { 목표 } \\
\text { 설정하기 }\end{array}$ & $\begin{array}{l}\text { - 유아교과교재 연구 및 지도법 교과에 } \\
\text { 서 내러티브 스토리텔링 수업 특성 및 } \\
\text { 학습목표 안내하기/이해하기 } \\
\text { - 내러티브 스토리텔링 목표 설정하기 } \\
\text { - 교수자와 학습자, 학습자와 학습자, } \\
\text { 학습자와 학습자료 간의 상호작용 방 } \\
\text { 법 안내하기 } \\
\text { - 팀원 간 수집한 자료 공유와 의사소통 } \\
\text { 하는 방법 안내하기 } \\
\text { - 내러티브 스토리텔링 연습시키기 } \\
\text { - On-line 학습공간 사용방법 안내하 } \\
\text { 기 } \\
\text { - 보고서 작성 방법 및 다양항 발표 방 } \\
\text { 법 안내하기/이해하기 }\end{array}$ & $\begin{array}{l}\text { - 유아교과교재 연구 및 지 } \\
\text { 도법 교과 관련 내러티브 } \\
\text { 스토리텔링 하습 목표 지 } \\
\text { 침 } \\
\text { - 과정 및 사용도구 가이드 } \\
\text { 라인 } \\
\text { - 내러티브 스토리텔링 각 } \\
\text { 단계별 지침 } \\
\text { - 최종결과물 작성시 유의 } \\
\text { 점 } \\
\text { - Presentation 지침 }\end{array}$ & $\begin{array}{l}\text { - 유아교과교재 연구 및 } \\
\text { 지도법 교과 관련 내러 } \\
\text { 티브 스토리텔링 소개 } \\
\text { info } \\
\text { - 아이디어 생성 도구/수 } \\
\text { 렴도구 info } \\
\text { - 운영상의 상호작용 info } \\
\text { - 스토리텔링 수업에서 학 } \\
\text { 습자 역할 info } \\
\text { - 온라인 커뮤니티 활용 } \\
\text { 방법 info } \\
\text { - 최종결과물 좋은 사례, } \\
\text { 실패한 사례 info } \\
\text { - Presentation 잘된 사례 } \\
\text { 와 실패한 사례 info }\end{array}$ & $\begin{array}{l}\text { - 유아교과교재 연구 및 } \\
\text { 지도법 교과 관련내러티 } \\
\text { 브 스토리텔링 수업과정 } \\
\text { 안내서 } \\
\text { - 의사소통 도구 } \\
\text { - 다양한 최종결과물 양식 } \\
\text { (웹진, 프리젠테이션 자 } \\
\text { 료, 보고서 등) } \\
\text { - 아이디어 생성 및 수렴 } \\
\text { 도구 }\end{array}$ & $\begin{array}{l}\text { - 교실환경 } \\
\text { - 온/오프라인을 통한 학습 } \\
\text { 지원 요소 지원 받음 }\end{array}$ \\
\hline $\begin{array}{c}\text { 스토리 주제 } \\
\text { 설정하기 }\end{array}$ & $\begin{array}{l}\text { - 다양한 경험 스토리 주제 제시하기/설 } \\
\text { 정하기 } \\
\text { - 아이디어 제안하기/아이디어 창출하 } \\
\text { 기 } \\
\text { - 아이디어 생성 도구 안내하기/사용하 } \\
\text { 기 } \\
\text { - Story Form 모델(1단계)-중요성 규 } \\
\text { 명하기 }\end{array}$ & $\begin{array}{l}\text { - 다양한 스토리 주제 설정 } \\
\text { 방법 지침 } \\
\text { - 아이디어 도구 사용 안내 } \\
\text { 서 } \\
\text { - Story Form 모델 (1단계) } \\
\text { 안내지침 }\end{array}$ & $\begin{array}{l}\text { - 다양한 스토리 주제 설 } \\
\text { 정 방법 예시 자료(동영 } \\
\text { 상, 창작동화 자료 등 } \\
\text { - 아이디어 생성도구 사용 } \\
\text { 방법 안내 자료 } \\
\text { - Story Form 모델 (1단계) } \\
\text { 안내자료 }\end{array}$ & $\begin{array}{l}\text { - 아이디어 생성도구 양식 } \\
\text { - Story Form 모델 (1단계) } \\
\text { 작성 양식 }\end{array}$ & $\begin{array}{l}\text { - 시청각 매체 } \\
\text { - Story Form 모델(1단계) } \\
\text { 안내자료 제공 }\end{array}$ \\
\hline $\begin{array}{c}\text { 스토리 } \\
\text { 공유하기 }\end{array}$ & $\begin{array}{l}\text { - 팀별 스토리 공유 방법 안내하기 } \\
\text { - 팀별 스토리 공유를 위해 발표하기/ } \\
\text { 탑재하기 } \\
\text { - Story Form 모델(1단계)-중요성 규 } \\
\text { 명하기 }\end{array}$ & $\begin{array}{l}\text { - 팀별 스토리 공유 방법 } \\
\text { 안내서 } \\
\text { - Story Form 모델(1단계) } \\
\text { 안내지침 }\end{array}$ & $\begin{array}{l}\text { - 팀별 스토리 공유 방법 } \\
\text { 안내 자료 } \\
\text { - Story Form 모델 (1단계) } \\
\text { 안내자료 }\end{array}$ & $\begin{array}{l}\text { - 아이디어 생성 도구 } \\
\text { - 아이디어 수렴도구 } \\
\text { - Story Form 모델 (1단계) } \\
\text { 작성 양식 }\end{array}$ & $\begin{array}{l}\text { - 팀별 스토리 공유 방법안 } \\
\text { 내자료 제시 } \\
\text { - 온/오프라인 학습지원요 } \\
\text { 소 제공 } \\
\text { - Story Form 모델(1단계) } \\
\text { 안내자료 제 공 }\end{array}$ \\
\hline
\end{tabular}




\begin{tabular}{|c|c|c|c|c|c|c|}
\hline \multirow{2}{*}{\multicolumn{2}{|c|}{$\begin{array}{l}\text { 학습과정 } \\
\text { 프로세스 }\end{array}$}} & \multirow{2}{*}{ 핵심학습활동(교수자/학습자) } & \multicolumn{3}{|c|}{ 핵심활동 지원요소 } & \multirow{2}{*}{ 학습환경 } \\
\hline & & & 안내지침 & 관련 정보 & 도구 & \\
\hline $\begin{array}{l}\text { 내 } \\
\text { 러 } \\
\text { 티 } \\
\text { 브 }\end{array}$ & $\begin{array}{c}\text { 역할 } \\
\text { 재구성하기 }\end{array}$ & $\begin{array}{l}\text { - 학습자 특성과 요구에 역할 제시하기 } \\
\text { - 과제 해절을 위한 팀원들의 역할 분담 } \\
\text { 재안내하기 } \\
\text { - 학습자 특성분석과 구성원 요구에 따 } \\
\text { 라 역할 재정비하기 } \\
\text { - 팀내 구성원의 역할 재구성하기(내러 } \\
\text { 티브 스토리텔링 과제 수행 시 개인 } \\
\text { 특기, 개인과 팀 모임 시간 고려, 불참 } \\
\text { 벅에 대한 조치 등 규칙 수립 안내) } \\
\text { - 팀내 구성원 역할 재정비를 위한 학습 } \\
\text { 자 자신의 내러터브 스토리텔링과 관 } \\
\text { 련한 지식, 자신의 겅험 이야기, 잘 하 } \\
\text { 는 것, 하고 싶고 배우고 싶은 역할 } \\
\text { 표현하기 } \\
\text { - 팀내 유능한 리더인 거실리테이터, 격 } \\
\text { 려자, 기록자, 점검자, 온라인 과제몰 } \\
\text { 탑재자 등 역할 재안내하기역할 재분 } \\
\text { 담하기 }\end{array}$ & \begin{tabular}{|l|} 
- 팀 구성원 역할 재정비 \\
밤법 지침 \\
- 아이디어 도구 안내 지침 \\
- 팀 규칙 재정비하기 지침 \\
- 팀 구성원 역할 재분담 \\
지침 \\
학습자 특성과 요구에 따 \\
른 역할 지침 \\
- 퍼실리테이터, 격려자, 기 \\
록자, 점검자, 온라인 과 \\
제물 탑재자 등 역할 지 \\
침
\end{tabular} & $\begin{array}{l}\text { - 팀 구성원 역할 재정비 } \\
\text { 를 방법 안내 자료 } \\
\text { - 팀 규칙 재정비 안내 자 } \\
\text { 료 } \\
\text { - 팀 구성원 역할 재분담 } \\
\text { 안내 자료 } \\
\text { - 학습자 특성과 요구에 } \\
\text { 따른 역할 안내 자료 } \\
\text { - 퍼실리테이터, 격려자, } \\
\text { 기록자, 점검자, 온라인 } \\
\text { 과제물 탑재자 등 역할 } \\
\text { 안내 자료 }\end{array}$ & $\begin{array}{l}\text { - 팀 구성원 역할 재정비 } \\
\text { 방법 양식 } \\
\text { - 팀 규칙 재정비 안내 자 } \\
\text { 료 } \\
\text { - 아이디어 도구 양식 } \\
\text { - 팀 규칙 재정비 지침 } \\
\text { - 팀 구성원 역할 재분담 } \\
\text { 약식 } \\
\text { - 학습자 특성과 요구 역 } \\
\text { 할 양식 } \\
\text { - 퍼실리테이터, 격려자, } \\
\text { 기록자, 제작자, 온라인 } \\
\text { 과제물 탑재자 등 역할 } \\
\text { 양식 }\end{array}$ & $\begin{array}{l}\text { - 온/오프라인 학습지원요 } \\
\text { 소 제공 } \\
\text { - 거실리테이터, 격려자, 기 } \\
\text { 록자, 점검자, 온라인 과 } \\
\text { 제물 답재자 등 역할 양 } \\
\text { 식 제공 } \\
\text { 온라인상에서 피드백 }\end{array}$ \\
\hline $\begin{array}{l}\text { 전 } \\
\text { 개 } \\
\text { 단 } \\
\text { 계 }\end{array}$ & $\begin{array}{c}\text { 컨셉 } \\
\text { 초안잡기 }\end{array}$ & $\begin{array}{l}\text { - 스토리에 대해 떠오르는 아이디어 안 } \\
\text { 내하기/기록하기 } \\
\text { - 발단, 전개, 위기, 절정, 결말 각 단계 } \\
\text { 에서 떠오르는 아이디어 안내하기/구 } \\
\text { 성하기 } \\
\text { - 주 아이디어와 대립아이디어로 안내 } \\
\text { 하기/기술하기 } \\
\text { - 아이디어 생성도구 사용방법 안내하 } \\
\text { 기 } \\
\text { - 컨셉 초안(발단, 전개, 위기, 절정, 결 } \\
\text { 말 } 5 \text { 단계) 방법 안내하기 } \\
\text { - Story Form 모델(2단계)-양분되는 } \\
\text { 극단찾기 }\end{array}$ & \begin{tabular}{|l|} 
\\
- 주 아이디어와 대립아이 \\
디어로 기술 안내 지침 \\
- 컨셉 초안 지침 \\
- Story Form 모델 (2단계) \\
안내지침
\end{tabular} & $\begin{array}{l}\text { - 스토리에 대해 떠오르는 } \\
\text { 아이디어 안내 자료 } \\
\text { - 발단, 전개, 위기, 절정, } \\
\text { 결말 아이디어안내 자료 } \\
\text { - 주 아이디어와 대립아이 } \\
\text { 디어로 기술 안내 자료 } \\
\text { - 컨셉초안 방법안내 자료 } \\
\text { - 컨셉 구조도 안내자료 } \\
\text { - 컨셉 흐름도 안내 자료 } \\
\text { - 컨셉 초안에 대한 사례 } \\
\text { info } \\
\text { - Story Form 모델 (2단계) } \\
\text { 안내자료 }\end{array}$ & $\begin{array}{l}\text { - 학습내용 구성하기 } \\
\text { - 아이디어 생성 도구(브 } \\
\text { 레인스토밍, 마인드 맵 } \\
\text { 등) } \\
\text { - 컨섭 구조도 } \\
\text { - 컨셉 흐름도 } \\
\text { - Story Form 모델 (2단계) } \\
\text { 작성 양식 }\end{array}$ & $\begin{array}{l}\text { - 온/오프라인 학습지원요 } \\
\text { 소 제공 } \\
\text { - 다양한 컨셉 도구와 자료 } \\
\text { 제공 } \\
\text { - 온라인상에서의 즉시적 } \\
\text { 인 피드백 } \\
\text { - Story Form 모델 (2단계) } \\
\text { 안내자료 제공 }\end{array}$ \\
\hline
\end{tabular}




\begin{tabular}{|c|c|c|c|c|c|}
\hline 학습과정 & \multirow{2}{*}{ 핵심학습활동(교수자/학습자) } & \multicolumn{3}{|c|}{ 핵심활동 지원요소 } & \multirow{2}{*}{ 학습환경 } \\
\hline 프로세스 & & 안내지침 & 관련 정보 & 도구 & \\
\hline $\begin{array}{c}\text { 컨섭 } \\
\text { 개요잡기 }\end{array}$ & $\begin{array}{l}\text { - 주제, 기획의도, 등장인물, 줄거리 등 } \\
\text { 간단한 방법 안내하기 / 개요 잡기 } \\
\text { - 핵심학습활동 안내하기 / 기술하기 } \\
\text { - Story Form 모델 (3단계)-스토리 만 } \\
\text { 들기 }\end{array}$ & $\begin{array}{l}\text { - 주제, 기획의도, 등장인 } \\
\text { 물, 줄거리 등 간단한 개 } \\
\text { 요 방법 지침 } \\
\text { - Story Form 모델 (3단계) } \\
\text { 안내지침 }\end{array}$ & $\begin{array}{l}\text { - 주제, 기획의도, 등장인 } \\
\text { 물, 줄거리 등 간단한 개 } \\
\text { 요 방법 안내 자료 } \\
\text { - 컨셉 개요잡기의 예시 } \\
\text { 자료 } \\
\text { - Story Form 모델 (3단계) } \\
\text { 안내자료 }\end{array}$ & $\begin{array}{l}\text { - 주제, 기획의도, 등장인 } \\
\text { 물, 줄거리 개요 양식 } \\
\text { - 핵 심학습활동 양식 } \\
\text { - Story Form 모델 (3단계) } \\
\text { 작성 양식 }\end{array}$ & $\begin{array}{l}\text { - 핵 심학습활동 양식 제공 } \\
\text { - 소소제프라공인 교수지원요 } \\
\text { - 온라인상에서의 즉시적 } \\
\text { 인 피드백 } \\
\text { - Story Form 모델 (3단계) } \\
\text { 안내자료 제 공 }\end{array}$ \\
\hline $\begin{array}{c}\text { 컨셉 } \\
\text { 구체화하기 }\end{array}$ & $\begin{array}{l}\text { - 줄거리 작성하기 } \\
\text { - 시놉시스 안내하기 / 작성하기 } \\
\text { - 플롯 안내하기 / 작성하기 } \\
\text { - 줄거리 작성 안내하기 } \\
\text { - 시놉시스 작성 안내하기 } \\
\text { - Story Form 모델 (4단계)-결론쓰기 }\end{array}$ & $\begin{array}{l}\text { - 줄거리 작성 지침 } \\
\text { - 시놉시스 작성 지침 } \\
\text { - 플롯 작성 지침 } \\
\text { - Story Form 모델 (4단계) } \\
\text { 안내지침 }\end{array}$ & $\begin{array}{l}\text { - 줄거리 작성 안내 자료 } \\
\text { - 시놉시스 작성 안내 자료 } \\
\text { - 플롯 작성 안내 자료 } \\
\text { - 컨셉 구체화하기에 대한 } \\
\text { 잘된 사례 info } \\
\text { - Story Form 모델 (4단계) } \\
\text { 안내자료 }\end{array}$ & $\begin{array}{l}\text { - 줄거리작성양식 } \\
\text { - 시놉시스 작성양식 } \\
\text { - 플롯 작성 양식 } \\
\text { - 컨셉 구체화하기에 대한 } \\
\text { 잘된 사례 양식 } \\
\text { - Story Form 모델 (4단계) } \\
\text { 작성 양식 }\end{array}$ & $\begin{array}{l}\text { - 줄거리, 시놉시스, 플롯 } \\
\text { 작성 양식 제공 } \\
\text { - 온/오프라인 학습지원요 } \\
\text { 소 제공 } \\
\text { - 온라인상에서의 즉시적 } \\
\text { 인 피드백 } \\
\text { - Story Form 모델 (4단계) } \\
\text { 안내자료 제 공 }\end{array}$ \\
\hline $\begin{array}{c}\text { 매체제작 } \\
\text { 방법 } \\
\text { 이해하기 }\end{array}$ & $\begin{array}{l}\text { - 다양한 동영상 프로그램 안내하기 / } \\
\text { 겅험해보기 } \\
\text { - 컴퓨터 동영상 프로그렘 안내하기 / } \\
\text { 학습하기 } \\
\text { - 퐈워포인트, 윈도우무비메이커 안내 } \\
\text { 하기 / 이해하기 } \\
\text { - 윈도우무비메이커 사용 안내하기 / 활 } \\
\text { 용하기 } \\
\text { - 윈도우무비메이커로 간단한 작업 안 } \\
\text { 내하기 / 겅험해보기 } \\
\text { - 두 개의 프로그렘 중 자신이 할 수 있 } \\
\text { 는 프로그램을 홯용하여 멀티미디어 } \\
\text { 그림첵을 제작할 수 있도록 안내하기 } \\
\text { / 멀티미디어 동화 제작 연습하기 } \\
\text { - 몇 개의 사진, 자막과 음향, 음성 등을 } \\
\text { 추가하면서 멀티미디어 동화 안내하 } \\
\text { 기제작하기 }\end{array}$ & $\begin{array}{l}\text { - 컴퓨터 동영상 프로그램 } \\
\text { 사용방법 지침 } \\
\text { - 퐈워포인트, 윈도우무비 } \\
\text { 메이커 사용방법 지침 } \\
\text { - 파워포인트, 윈도우무비 } \\
\text { 메이커 홯용방법 지친 } \\
\text { - 퐈워포인트, 윈도우무비 } \\
\text { 메이커 간단한 작업 지첨 } \\
\text { - 멀티미디어 동화 제작 안 } \\
\text { 내 지침 }\end{array}$ & $\begin{array}{l}\text { - 컴퓨터 동영상 프로그램 } \\
\text { 사용방법 안내 자료 } \\
\text { - 파워포인트, 윈도우무비 } \\
\text { 메이커 사용방법 안내 } \\
\text { 자료 } \\
\text { - 파워포인트, 윈도우무비 } \\
\text { 메이커 활용방법 안내 } \\
\text { 자료 } \\
\text { - 파워포인트, 윈도우무비 } \\
\text { 메이커로 간단한 작업 } \\
\text { 안내 자료 } \\
\text { - 멀티미디어 동화 제작 } \\
\text { 안내 자료 } \\
\text { - 파워포인트, 원도우무비 } \\
\text { 메이커로 제작한 잘된 } \\
\text { 사례 info }\end{array}$ & $\begin{array}{l}\text { - 컴퓨터 동영상 프로그램 } \\
\text { 사용방법 양식 } \\
\text { - 원도우무비메이커 사용 } \\
\text { 방법 양식 } \\
\text { - 윈도우무비메이커 활용 } \\
\text { 방법 양식 } \\
\text { - 윈도우무비메이커로 간 } \\
\text { 단한 작업 양식 } \\
\text { - 멀티미디어 동화 제작 } \\
\text { 안내 양식 } \\
\text { - 잘된 사레 양식 }\end{array}$ & $\begin{array}{l}\text { - 온/오프라인 학습지원요 } \\
\text { 소 제공 } \\
\text { - 온라인상에서의 즉시적 } \\
\text { 인 피드배 } \\
\text { - Story Form 모델(4단계) } \\
\text { 안내자료 제 공 }\end{array}$ \\
\hline
\end{tabular}




\begin{tabular}{|c|c|c|c|c|c|c|}
\hline & 학습과정 & \multirow{2}{*}{ 핵심학습활동(교수자/학습자) } & \multicolumn{3}{|c|}{ 핵심활동 지원요소 } & \multirow{2}{*}{ 학습환경 } \\
\hline & 프로세스 & & 안내지침 & 관련정보 & 도구 & \\
\hline & $\begin{array}{l}\text { 비주얼 } \\
\text { 시나리오 } \\
\text { 작성하기 }\end{array}$ & $\begin{array}{l}\text { - 비주얼 시나리오 안내하기/구성하기 } \\
\text { - 비주얼 시나리오 작성 방법 안내하기/ } \\
\text { 구성하기 } \\
\text { - Scene에서 핵심학습활동 안내하기/ } \\
\text { 기술하기 } \\
\text { - 비주얼 시나리오 작성 방법 안내하기 }\end{array}$ & $\begin{array}{l}\text { - 비주얼 시나리오 작성 방 } \\
\text { 법 지침 } \\
\text { - 비주얼 시나리오 구성 지 } \\
\text { 침 } \\
\text { - Scene에서 핵심학습활동 } \\
\text { 기술 지침 }\end{array}$ & $\begin{array}{l}\text { - 비주얼 시나리오 작성 } \\
\text { 방법 안내 자료 } \\
\text { - 비주얼 시나리오 구성 } \\
\text { 안내 자료 } \\
\text { - Scene에서 핵심학습활 } \\
\text { 동 기술 안내 자료 }\end{array}$ & $\begin{array}{l}\text { - 비주얼 시나리오 작성 } \\
\text { 양식 }\end{array}$ & $\begin{array}{l}\text { - 온/오프라인 학습지원요 } \\
\text { 소 제공 } \\
\text { - 비주얼 시나리오 작성 양 } \\
\text { 식 제공 } \\
\text { - 온라인상에서의 즉시적 } \\
\text { 인 피드백 }\end{array}$ \\
\hline & $\begin{array}{l}\text { 스토리보드 } \\
\text { 작성하기 }\end{array}$ & $\begin{array}{l}\text { - 스토리보드 작성 안내하기 / 작성하기 } \\
\text { - 화면 구성하기 }\end{array}$ & $\begin{array}{l}\text { - 스토리보드 작성 지침 } \\
\text { - 화면 구성 지침 }\end{array}$ & $\begin{array}{l}\text { - 스토리보드 작성 안내 } \\
\text { 자료 } \\
\text { - 화면 구성 안내 자료 }\end{array}$ & $\begin{array}{l}\text { - 스토리보드 작성 양식 } \\
\text { - 화면 구성양식 }\end{array}$ & $\begin{array}{l}\text { - 온/오프라인 학습지원요 } \\
\text { 소 제공 } \\
\text { - 스토리보드 사례 제공 } \\
\text { - 온라인상에서의 즉시적 } \\
\text { 인 피드백 }\end{array}$ \\
\hline & $\begin{array}{l}\text { 학습결과물 } \\
\text { 도출하기 }\end{array}$ & $\begin{array}{l}\text { - 학습결과물계획 과정 코칭하기 } \\
\text { - 학습결과물계획 세우기 } \\
\text { - 멀티미디어 매체 제작 방법 안내하기 } \\
\text { / 제작하기 }\end{array}$ & $\begin{array}{l}\text { - 학습결과물계획 세우기 } \\
\text { 지침 } \\
\text { - 학습결과물도출 계획 지 } \\
\text { 침 } \\
\text { - 학습결과물 계획 세우기 } \\
\text { 지침 } \\
\text { - 멀티미디어 매체 제작 방 } \\
\text { 법 지침 }\end{array}$ & $\begin{array}{l}\text { - 학습결과물 info } \\
\text { - 학습걸과물 계획세우기 } \\
\text { 안내 자료 } \\
\text { - 학습결과물 활용방법 } \\
\text { info } \\
\text { - 학습걸과물을 도출하기 } \\
\text { 위해 계획 안내 자료 } \\
\text { - 멀티미디어 매체 제작 } \\
\text { 방법 안내 자료 }\end{array}$ & $\begin{array}{l}\text { - 학습걸과물 계획세우기 } \\
\text { 양식 } \\
\text { - 학습결과물 도출 양식 } \\
\text { - 멀티미디어 매체 제작 } \\
\text { 방법 지침 } \\
\text { - 아이디어 생성 및 수렵 } \\
\text { 도구 }\end{array}$ & $\begin{array}{l}\text { - 온/오프라인 학습지원요 } \\
\text { 소 제공 } \\
\text { - 학습결과물 도출 사례 제 } \\
\text { 공 } \\
\text { - 온라인상에서의 즉시적 } \\
\text { 인 피드백 }\end{array}$ \\
\hline $\begin{array}{l}\text { 스 } \\
\text { 토 } \\
\text { 리 } \\
\text { 텔 } \\
\text { 링 }\end{array}$ & $\begin{array}{l}\text { 학습결과물 } \\
\text { 공유 및 } \\
\text { 발표하기 }\end{array}$ & $\begin{array}{l}\text { - 학습결과물 공유 안내하기 } \\
\text { - 원활한 발표 활동 환경 조성하기 } \\
\text { - 학습결과물 다양한방법 발표안내/발 } \\
\text { 표하기 } \\
\text { - 학습결과 발표 촉진하기 } \\
\text { - 학습결과물 공유 온라인 공간 안내/탑 } \\
\text { 재하기 } \\
\text { - 결과 공유 관리하기 } \\
\text { - 다른 팀의 의견 존중하여 피드백 주기 } \\
\text { - 발표된 학습 결과 문제 해결안에 대해 } \\
\text { 적절한 피드백 제공하기 }\end{array}$ & $\begin{array}{l}\text { - 학습결과물 공유 지침 } \\
\text { - 학습결과물 발표 유의점 } \\
\text { 지침 } \\
\text { - 학습결과물에 대한 피드 } \\
\text { 백 지침 } \\
\text { - 발표 환경 조성 지침 }\end{array}$ & $\begin{array}{l}\text { - 학습결과물 공유안내 자 } \\
\text { 료 } \\
\text { - 학습결과물 발표 안내 } \\
\text { 자 } \\
\text { - 학습결과물 탑재안내 자 } \\
\text { 료 } \\
\text { - 학습결과물 발표 잘된 } \\
\text { 사례 자료 }\end{array}$ & $\begin{array}{l}\text { - 학습결과물 공유 양식 } \\
\text { - 학습결과물 발표 양식 } \\
\text { - 아이디어 수렴도구양식 }\end{array}$ & $\begin{array}{l}\text { - 온/오프라인 학습지원요 } \\
\text { 소 제공 } \\
\text { - 발표 가능 교실환경 } \\
\text { - 온/오프라인 과제물 탑재 } \\
\text { 제공 } \\
\text { - 온라인상에서의 즉시적 } \\
\text { 인 피드백 }\end{array}$ \\
\hline
\end{tabular}




\begin{tabular}{|c|c|c|c|c|c|c|}
\hline & 학습과정 & \multirow{2}{*}{ 핵 심학습활동(교수자/학습자) } & \multicolumn{3}{|c|}{ 핵심활동 지원요소 } & \multirow{2}{*}{ 학습환경 } \\
\hline & 프로세스 & & 안내지침 & 관련 정보 & 도구 & \\
\hline & 리텔링하기 & $\begin{array}{l}\text { - 학습걸과물에 대한 교육계획안 작성 } \\
\text { 안내하기 / 계획세우기 } \\
\text { - 교육계획안 작성하기 } \\
\text { - 교사와 유아 여할정하기 } \\
\text { - 모의수업 안내하기 / 시연하기 } \\
\text { - 교사와 유아 역할 안내하기 }\end{array}$ & $\begin{array}{l}\text { - 학습걸과물에 대한 교육 } \\
\text { 계획안 지침 } \\
\text { - 교육계획안작성 지침 } \\
\text { - 교사, 유아여할 지친 } \\
\text { - 시연 지침 } \\
\text { - 모의수업 지침 }\end{array}$ & $\begin{array}{l}\text { - 학습결과물에 대한 교육 } \\
\text { 계획안 안내 자료 } \\
\text { - 교육계획안 작성하기 } \\
\text { - 교사와 유아 역할 안내 } \\
\text { 자료 } \\
\text { - 시연 안내 자료 } \\
\text { - 모의수업 안내 자료 }\end{array}$ & $\begin{array}{l}\text { - 학습절과물에 대한 교육 } \\
\text { 계획안 양식 } \\
\text { - 교육계획안 작성 양식 } \\
\text { - 시연 양식 } \\
\text { - 모의수업 양식 }\end{array}$ & $\begin{array}{l}\text { - 온/오프라인 학습지원요 } \\
\text { 소 제공 } \\
\text { - 표실환겅에서 시연 제공 } \\
\text { - 교실환경에서 모의수업 } \\
\text { 제공 }\end{array}$ \\
\hline $\begin{array}{l}\text { 마 } \\
\text { 무 } \\
\text { 리 } \\
\text { 단 } \\
\text { 계 }\end{array}$ & $\begin{array}{c}\text { 평가하기 및 } \\
\text { 성찰하기 }\end{array}$ & $\begin{array}{l}\text { - 도출된 최종 결과물을 공유 및 누적 } \\
\text { 관리될 수 있도록 조언하기 } \\
\text { - 팀원, 팀 간 성찰활동 안내하기 } \\
\text { - 팀원, 팀 간 성찰활동 하기 } \\
\text { - 각 단계별 성찰활동하기 } \\
\text { - 개인별 성찰홤동 안내하기/ 성찰하기 } \\
\text { - 반성적 성찰활동 안내/ 성찰하기 } \\
\text { - 최종 학습결과물 팀별 평가하기 } \\
\text { - 각 단계별 자가 평가 안내하기/ 촉진 } \\
\text { 하기 } \\
\text { - 평가활동하기 } \\
\text { - 산출된 학습 걸과물들을 온라인 학습 } \\
\text { 공간 공유 및 탑재 관리하기 } \\
\text { - 온라인 공간에 탑재된 학습과정 산출 } \\
\text { 물 평가 실시하기 } \\
\text { - 교수자 각 단계별 평가하기 } \\
\text { - Egan의 Story Form 모델(5단계)-평 } \\
\text { 가하기 }\end{array}$ & $\begin{array}{l}\text { - 학습결과물에 대한 교수 } \\
\text { 자의 평가 지침 } \\
\text { - 팀간 피드백촉진 지침 } \\
\text { - 학습결과물공유 지침 } \\
\text { - 학습결과물 공유를 위한 } \\
\text { 질문 지침 } \\
\text { - 개인별 성찰활동지침 } \\
\text { - 학습자성찰활동지침 } \\
\text { - 팀간 성찰활동 지침 } \\
\text { - 성찰활동 질문 지침 } \\
\text { - 수업 성찰활동 지침 } \\
\text { - 최종결과물 평가지침 } \\
\text { - 수업 단계별 평가 지침 } \\
\text { (학습자, 교수자용) } \\
\text { - 학습자 자가 평가를 위한 } \\
\text { 촉발질문 지침 } \\
\text { - Story Form 모델 (5단계) } \\
\text { 안내지침 }\end{array}$ & $\begin{array}{l}\text { - 학습결과 피드백방법/피 } \\
\text { 드백 촉발질문 샘플자료 } \\
\text { - 교수자 피드백 방법 } \\
\text { - 학습결과물 공유 및 관 } \\
\text { 리 잘된 사례 } \\
\text { - 결과물 공유질문 안내자 } \\
\text { 료 } \\
\text { - 각 프로세스별 성찰활동 } \\
\text { 방법 안내 자료 } \\
\text { - 성찰활동 질문예시 자료 } \\
\text { - 개인별, 팀원간 성찰활 } \\
\text { 동 방법 안내 자료 } \\
\text { - 웹 커뮤니티 탑재 학습 } \\
\text { 과정 결과물평가 방법 } \\
\text { - 최종걸과몰 평가 방법 } \\
\text { - 학습자 자가 평가를 위 } \\
\text { 한 질문 예시 자료 } \\
\text { - Story Form 모델 (5단계) } \\
\text { 안내자료 }\end{array}$ & $\begin{array}{l}\text { - 문제해결안 평가지 } \\
\text { - 그룹별 발표 평가표 } \\
\text { - 웹커뮤니티 } \\
\text { - 학습자성찰활동지 } \\
\text { - 팀원활동성찰지 } \\
\text { - 교수자 역할 자가진단도 } \\
\text { 구 } \\
\text { - 학습자용 내러티브 스토 } \\
\text { 리텔링 수업 평가도구 } \\
\text { - 교수자용 수업 평가 도 } \\
\text { 구 } \\
\text { - 팀활동 평 가표 } \\
\text { - 성찰일지평가표 } \\
\text { - Story Form 모델 (5단계) } \\
\text { 작성 양식 }\end{array}$ & $\begin{array}{l}\text { - 학습결과물 평가표 등의 } \\
\text { 학습지원요소 제공 환경 } \\
\text { - 최종 결과물 온라인 탑재 } \\
\text { 관리 환경 } \\
\text { - 성찰활동지 등의 학습지 } \\
\text { 원요소 및 교수자 성찰활 } \\
\text { 동 지침 제공 환경 } \\
\text { - 온라인 공간에 탑재된 데 } \\
\text { 이터 평가 가능 환경 } \\
\text { - 교수자 및 학습자 평가 } \\
\text { 지원요소 제 공 환경 } \\
\text { - 온/오프라인 교수지원 요 } \\
\text { 소 제 공 } \\
\text { - Story Form 모델 (5단계) } \\
\text { 안내자료 제공 }\end{array}$ \\
\hline
\end{tabular}




\section{IV. 결론 및 제언}

본 연구는 유아교과교재 연구 및 지도법 교과수업에서 내러티브 스토리텔링 수업설계안을 구 안하는 것이며, 이를 위해 문헌분석, 사례분석, 전문가와 수업적용 형성평가를 통한 개선점을 바 탕으로 수정·보완하여 최종안을 구안하였다. 연구결과를 중심으로 논의하면 다음과 같다.

첫째, 내러티브 스토리텔링의 특성을 반영하고 있는 본 수업설계안은 $\operatorname{Egan(1986)ㅇㅢ~ㅅㅡㅌㅗㄹㅣㅎㅕㅇ~}$ 식 모형(Story Form Model)과 비교하는 과정을 거쳐, 교수매체 제작과 개발에 필요한 구체적인 안내와 지원을 보완하여 구안하였다. 특히, 내러티브 스토리텔링 수업은 성찰을 통해 활동을 점 검하고, 각 단계의 결과물은 다음 단계의 입력 자료가 될 수 있는 각 단계별 수업이 서로 연결되 고 이어지는 연동성이 존재한다. 본 연구는 유아교육 분야에서 수업설계와 관련하여 교수매체 제작과 개발에 대한 구체적인 안내와 지원, 체계화된 청사진이 없으며, 수업의 분절성(김영천, 2010; 이영석, 2003; 조희정, 이대균, 2012)에 대한 논의를, $\operatorname{Egan}(1986)$ 에 근거하여 각 단계별 구 체적인 지원요소와 성찰이 이루어지는 절차적 청사진을 제공하였다는 측면에서 차별성을 둘 수 있다. 본 수업설계는 유아교사의 다양한 수준에 적합한 수업 요구를 고려하여, 교수신념이 확립 되지 않은 예비유아교사인 학습자의 특성을 고려하여 수업목표, 환경에 맞게 선정, 제작, 개발함 으로써 수업의 효율성을 높여 줄 수 있을 것이다.

둘째, 예비유아교사들은 수업의 각 단계를 자연스럽게 이해할 수 있고, 재생가능한 매체제작 과 감각적인 성찰활동을 통해 피드백, 피드포워드 될 수 있는 순환적인 사고와 과제해결의 기회 를 가질 수 있었다. 이러한 결과는 다양한 수업에서 학습자에게 스토리텔링의 기회를 제공하고 플롯의 속성, 가상의 인물들 간의 대립과 갈등 해결, 학습자의 흥미, 능동적인 참여와 몰입, 학습 동기와 학업성취도, 문제해결, 타인에 대한 이해와 원활한 상호작용의 학습효과의 긍정적인 결 과를 밝힌 연구들(허희옥, 2006; Egan, 1986; Georges, 1985)과 부합된다. 즉, 수업(Instructional) 은 인간 의미와 해석의 미묘하고 측정불가능한 주관적인 과정이 생략되고 분절된다는(김영천, 2010) 우려의 인식에서 벗어나, 수업설계(Instructional Design)는 인간이 실제 세계를 이해하고, 생생한 경험 이야기의 핵심을 바탕으로 상황맥락적인 수업으로 이해되어져야 할 것이다. 따라서 교사는 전달 방식을 고려할 때, 학습자들이 교육내용을 얼마나, 어떻게 인식하고 있는가를 파악 할 수 있어야 한다. 이러한 의미에서 본 수업은 단편적인 조각수업이 가지는 분절성을 극복하고, 다음 수업으로 이어지는 수업과 수업 사이의 맥락성을 가지게 된다.

셋째, 내러티브 스토리텔링 수업은 이미 존재하는 스토리의 수업이(김수향, 2009) 아니라, 교 수자와 학습자의 경험과 삶을 재구성하는 이야기 의미 생성과정이다. 즉, 내러티브 스토리텔링 수업은 창의력, 의미구성, 상황맥락적 이해력 등을 길러 줄 수 있는 지식정보 창출의 의미 구조 화 방식이다. 스토리텔링 수업은 '내러티브'이며, 수업의 맥락을 구성하고 주도하는 것은 이야기 
이다. 이야기 안에서 수업 활동을 시작하고 배우고 성장하고 마무리한다. 이야기 구성은 $\operatorname{Egan}(1992)$ 의 신화적 단계를 고려하여 풍부한 장면, 캐릭터, 갈등 해결이 잘 구성되고, 발단, 전 개, 위기, 절정, 결말의 복합적인 플롯을 가진 흥미로운 이야기를 재창조해야 한다. 이 때, 수업설 계를 하고 학습목표에 따른 주제를 구성한 후에 그 주제에 따른 교육 메시지를 스토리에 넣어야 한다. 학습목표와 주제를 구성하지 않고 내러티브를 할 경우, 내러티브의 내용과 주제 전개과정 이 연결되지 않아 이야기의 맥락과 수업활동의 연결이 원활하지 않을 수도 있다.

수업에서 학생들의 창의적인 아이디어 구상은 놀라울 정도로 다양하였다. 도입단계에서 그들의 개인적이고 사회적인 삶의 경험 이야기를 나누었고, 예비유아교사 내면의 아름다움과 감성이 내재 된 스토리로 구현되었다. 리텔링단계는 스토리를 전달하는 목소리의 여운에서 미래의 스토리 개발 자 내지는 스토리텔러의 모습을 엿볼 수 있었다. 또한, 교사가 될 예비유아교사는 '진정한 수업'에 대한 성찰 즉 '교육이란 무엇인가' '교육한다는 것은 무엇인가? 하는 질문에 대한 성찰이 필요하다. 왜냐하면, 교사는 그들의 삶에서 경험과 교육적 의미를 살아있는 수업에서 지속적으로 증명해야 하 기 때문이다(2013. 5. 30. 연구자의 저널).

학습자들은 본 수업을 통해 단계별 성찰과 협력적 관계를 유지하고, 적극적으로 참여할 수 있음을 긍정적으로 보여주고 있다. 교과수업에서 경험 이야기, 일지나 저널쓰기, 편지쓰기, 이야 기 포트폴리오 등 경험적 이야기 구성과 모든 이용 가능한 매체에 의해 개발되고 유지된 포트폴 리오 등을 실행할 수 있다. 이러한 수업은 교육적 상황 속에서 교수자와 학습자가 함께 만들어 가는 구두(이야기), 서면(텍스트), 대리(비디오, 사진, 오디오 레코딩, 공예품, 드라마, UCC 등) 내러티브(Richard, 1994) 등으로 최종의 텍스트가 산출될 수 있을 것이다. 또한, 내러티브 스토리 텔링 수업은 이야기를 구성하고 표현하도록 도우며, 과거와 현재를 이해하고, 관리하며 미래를 계획하기 위한 세상의 자원을 사용하고, 우리 삶에 의미를 부여하는 경험적 이야기가 교육적 메 시지로 이어질 수 있는 즉, 수업을 다시 디자인하는 내러티브 교육학(Richard, 1994)을 기대한다.

본 수업설계는 연구자와 현장 전문가, 실제 교육현장의 목소리와 맥락을 반영하는 적응적, 순 환적, 상황적 연구방법으로 실천적인 수업설계안을 제공해 줄 수 있다. 그러나 본 연구는 연구자 가 직접 강의하는 특정 학교, 학과, 교과를 중심으로 개발된 것으로, 다양한 수업현장과 대상에 적용이 가능할 것인지의 일반화에 대한 의문이 있다. 따라서 유아교사교육과정에서 후속연구를 위한 지속적인 검증 절차가 필요하다. 


\section{참고문헌}

강문숙, 김석우(2012). 내러티브 스토리텔링의 교육적 효용성에 대한 학습자 인식 연구. 사고개 발, 8(2), 83-106.

강현석(2005). 합리주의적 교육과정 체제에서 배제된 내러티브 교육과정의 가능성과 교과목 개

발의 방향 탐색. 교육과정연구, 23(2), 83-115.

강현석, 유동희, 이자현, 이대일(2005). 내러티브 활용을 통한 교과교육론 구성 방향의 탐색. 한

국교원교육연구, 22(3), 215-241.

김수향(2009). 유아의 그림책을 활용한 창의적 문제해결능력과 창의적 사고에서의 성차. 사고개

발, $4(2), 33-52$.

김영천(2006). 질적연구방법론 I. 서울: 문음사.

김영천(2010). 네 학교 이야기 : 한국초등학교의 교실생활과 수업. 서울: 문음사.

박향원, 임부연(2012). 내러티브에 기초한 유아심미교육의 질적 사례연구. 어린이미디어연구, 11(3), 49-84.

변영계, 이상수(2009). 수업설계. 서울: 학지사.

이영석(2003). 유아의 발달에 적합한 유아 수업모형 탐색 연구. 미래유아교육학회지, 10(1), 167-206.

임수진, 이혜원(2010). 예비유아교사의 과학교육 수업경험에 대한 내러티브 탐구 : 자원기반학습 을 중심으로. 생태유아교육연구, 9(2), 41-63.

전현정, 강현석(2009). 대안적 초등교육과정 개발 방향 탐색-Egan의 이야기 형식 모형을 중심으 로. 초등교육연구, 22(1), 169-198.

조희정, 이대균(2012). ASSURE 모형에 기초한 예비유아교사의 모의수업분석. 열린유아교육연 구, 17(3), 283-311.

허희옥(2006). 내러티브 스토리텔링 기법을 이용한 멀티미디어 교육컨텐츠 개발. 교육공학연구, 22(1), 195-224.

Blenkin, G. M., \& Kelly, A. V. (1981). The primary curriculum London: Harper \& Row, publishers.

Clandinin, J., \& Connelly, F. M. (2000). Narrative inquiry: experience and story in qualitative research San Francisco. CA: Jossy-Bass Inc.

Egan, Kieran. (1986). Primary Understanding: education in early childhood New York and London: Routhledege. 
Egan, Kieran. (1986). Teaching as Story Telling: An alternative approach to teaching and curriculum Chicago, IL: University of Chicago Press.

Egan, Kieran.(1992). Imagination in teaching and learning. The middle school years. Chicago: The University of Chiago Press.

Fusai, C., Saudelli, B., Marti, P., Decortis, F., \& Rizzo, A. (2003). Media composition and narrative performance at school. Journal of Computer Assisted Learning, 19, 177-185.

Georges, I.. (1990). 신비로운 수의 역사. [LES CHIFFERES ou l'histoire d'une grande invention]. (김병욱 역). 서울: 예하. (원본발간일 1985년).

Jonassen, D. H., \& Hernandez-serrano, Julian (2002). Case-based reasoning and instructional design: Using stories to support problem-solving. Educational Technology Research . Development, 5q(2), 65-77.

Lincoln, Y. S., \& Guba, E. G. (1985). Naturalistic Inquiry. Beverly Hills, CA: Sage.

Macdonald, J. B. (1966). The Person in the Curriculum. In Helen R. F. (Eds.) Precedents and Promise in the Curriculum Field New York: Teachers College Press. pp. 38-52.

Polkinghorne, D. E. (1988). Narrative knowing and the human science. Albany, NY: SUNY press. Richard L. H. (1994). NARRATIVE SCHOOL: Experiential Learning and the Transformation of American Education. Teachers College Press, New York, N. Y.: EYA.

Richey, R. C. \& Nelson, W. A. (1996). Developmental research In Jonassen, D. H. (Ed.). Handbook of research for Educational Communications and Technology. (pp. 1213-1245). New York: Macmillan.

Ryan, M. L. (2004). Narrative across media: The language of storytelling. Lincoln. NE: University of Nebraska Press.

* 논문접수 2014년 2월 5일 / 1차 심사 2014년 3월 14일 / 2차 심사 2014년 3월 25일 / 게재승인 2014년 3월 25일

* 강문숙: 부산대학교에서 유아교육과 교육학 석사학위와 -멀티미디어협동과정 교육공학전공 이학박사 학위를 취득하였고, 동대학교 교육발전연구소 Post-Doc연구원, 현재 한국국제대학교 유아교육과 조교수로 재직 중이다. 주요논문으로는 'A Study on the Development of an Educational UCC Model for Pre-Service Early Childhood Teachers at the University', '유아문학교육 교과수업을 위한 교수설계 모형 개발, '내러티브 스토리텔링의 교육적 효용성에 대한 학습자 인식 연구, '예비유아교사를 위한 블렌디드 러닝기반 스토리텔링 수업모형 개발: 멀티미디어 창작동화 수업을 중심으로' 등이 있다.

*E-mail: anstnr3903@live.co.kr 
Abstract

\section{Development of Instructional Design Narrative Storytelling for Pre-service Early Childhood Teachers}

Kang, Mun-Suk*

The purpose of this study is to develop an Instructional Design Model based on the narrative storytelling for pre-service early childhood teachers. To achieve this purpose, the study was divided into two stages. First, the draft of Instructional Design Mode was proposed by performing a literature survey and a case study. Second, the draft model was applied to the actual work. And the draft was modified to the final model on the basis of the draft model's strength. It was implemented with 35 students who were sophomores in the early childhood department and a H University, J city for 10 weeks. To accomplish this study, first of all, this research analyzed the core values, design strategy, optimal learning activity process, and its supporting components. These components were integrated into the desired model, which was selected after the needs analysis and the literature review of the theories and the cases regarding the pre-service early childhood teacher. Secondly, the study synthesized the relevant components from the previous research activities and generated the first version of the model prototype. This study identified the four core values as: systemic support for learning activity, systematic support for learning activity, just in time support for learning activity and support for interaction facilitation. From the implementation result of the model, it was determined that there was a positive reaction on applying narrative storytelling technique to the beginning stage of narrative storytelling based learning. And adding the 're-constitution role sharing team' step into the original steps was suggested.

Key words: pre-service early childhood teachers, narrative storytelling, instructional design

* First author, Assistant professor, International University of Korea 